\title{
CTLA4-Ig treatment induces M1-M2 shift in cultured monocyte-derived macrophages from healthy subjects and rheumatoid arthritis patients
}

\author{
Maurizio Cutolo ${ }^{1^{* \dagger}} \mathbb{B}$, Stefano Soldano ${ }^{1 \dagger}$, Emanuele Gotelli ${ }^{1}$, Paola Montagna ${ }^{1}$, Rosanna Campitiello ${ }^{1}$, \\ Sabrina Paolino ${ }^{1}$, Carmen Pizzorni ${ }^{1}$, Alberto Sulli ${ }^{1}$, Vanessa Smith ${ }^{2,3,4}$ and Samuele Tardito ${ }^{1}$
}

\begin{abstract}
Background: In rheumatoid arthritis (RA), macrophages play an important role in modulating the immunoinflammatory response through their polarisation into "classically" (M1) or "alternatively activated" (M2) phenotypes. In RA, CTLA4-Ig (abatacept) reduces the inflammatory activity of macrophages by interacting with the costimulatory molecule CD86. The study aimed to investigate the efficacy of CTLA4-Ig treatment to induce an M2 phenotype both in M1-polarised monocyte-derived macrophages (MDMs) obtained from healthy subjects (HS) and in cultured MDMs obtained from active RA patients.

Methods: Cultured MDMs were obtained from peripheral blood mononuclear cells of 7 active RA patients and from $10 \mathrm{HS}$ after stimulation with phorbol myristate acetate $(5 \mathrm{ng} / \mathrm{mL})$ for $24 \mathrm{~h}$. HS-MDMs were then stimulated with lipopolysaccharide (LPS, $1 \mathrm{mg} / \mathrm{mL}$ ) for $4 \mathrm{~h}$ to induce M1-MDMs. M1-MDMs and RA-MDMs were treated with CTLA4$\lg (100 \mu \mathrm{M}$ and $500 \mu \mathrm{M})$ for 3, 12, 24, and $48 \mathrm{~h}$. The gene expression of CD80, CD86, and TLR4 (M1 markers); CD163, CD204, and CD206 (surface M2 markers); and MerTK (functional M2 marker) was evaluated by qRT-PCR. The protein synthesis of surface M2 markers was investigated by Western blotting. The statistical analysis was performed by the Wilcoxon $t$-test.

Results: In LPS-induced HS-M1-MDMs, CTLA4-Ig $100 \mu \mathrm{M}$ and $500 \mu \mathrm{M}$ significantly downregulated the gene expression of M1 markers ( $3 \mathrm{~h} p<0.01$ for all molecules; $12 \mathrm{~h} p<0.05$ for TLR4 and CD86) and significantly upregulated that of M2 markers, primarily after $12 \mathrm{~h}$ of treatment (CD163: $p<0.01$ and $p<0.05$; CD206: $p<0.05$ and $p<0.01$; CD204: $p<0.05$ by $100 \mathrm{mg} / \mathrm{mL}$ ). Moreover, in these cells, CTLA4-Ig $500 \mu \mathrm{M}$ increased the protein synthesis of surface M2 markers $(p<0.05)$. Similarly, in RA-MDMs, the CTLA4-Ig treatment significantly downregulated the gene expression of M1 markers at both concentrations primarily after $12 \mathrm{~h}(p<0.05)$. Furthermore, both concentrations of CTLA4-Ig significantly upregulated the gene expression of CD206 (after 3 h of treatment; $p<0.05$ ), CD163, and MerTK (after 12 h of treatment, $p<0.05$ ), whereas CD204 gene expression was significantly upregulated by the high concentration of
\end{abstract}

\footnotetext{
*Correspondence: mcutolo@unige.it

${ }^{\dagger} \mathrm{M}$ Cutolo and S Soldano shared the first authorship.

${ }^{1}$ Laboratory of Experimental Rheumatology and Academic Division of Clinical Rheumatology, Department of Internal Medicine, IRCCS San Martino Polyclinic Hospital, University of Genova, Genoa, Italy

Full list of author information is available at the end of the article
} permits use, sharing, adaptation, distribution and reproduction in any medium or format, as long as you give appropriate credit to the original author(s) and the source, provide a link to the Creative Commons licence, and indicate if changes were made. The images or other third party material in this article are included in the article's Creative Commons licence, unless indicated otherwise in a credit line to the material. If material is not included in the article's Creative Commons licence and your intended use is not permitted by statutory regulation or exceeds the permitted use, you will need to obtain permission directly from the copyright holder. To view a copy of this licence, visit http://creativecommons.org/licenses/by/4.0/. The Creative Commons Public Domain Dedication waiver (http://creativeco mmons.org/publicdomain/zero/1.0/) applies to the data made available in this article, unless otherwise stated in a credit line to the data. 
CTLA4-Ig $(p<0.05)$. The protein synthesis of all surface markers was increased primarily by CTLA4-Ig $500 \mu \mathrm{M}$, significantly for CD204 and CD206 after $24 \mathrm{~h}$ of treatment $(p<0.05)$.

Conclusions: CTLA4-Ig treatment seems to induce the in vitro shift from M1 to M2 macrophages, of both HSM1-MDMs and RA-MDMs, as observed by the significant downregulation exerted on selected M1 markers and the upregulation of selected M2 markers suggesting an additional mechanism for its modulation of the RA inflammatory process.

Keywords: CTLA4-Ig, Abatacept, Monocytes, Macrophages, Rheumatoid arthritis, M1-M2 polarisation, Autoimmune

\section{Introduction}

Rheumatoid arthritis (RA) is a complex autoimmune disease characterised by chronic inflammation leading to progressive disability, mainly involving synovial joints, and affecting approximately $1 \%$ of the population worldwide [1-3]. The mechanisms underlying the inflammation in RA have been analysed in many immunological studies shedding light on the role of innate immunity in modulating the adaptive immunity, controlling the immune response at different levels and mediating the induction, as well as the progression, of persistent inflammation $[4,5]$.

Among the inflammatory cells involved in RA, macrophages potentially play a central pathogenic role contributing to the chronicity of the disease [4-8]. Macrophages invading the synovial tissue are stimulated to release cytokines, primarily tumour necrosis factor- $\alpha$ (TNF $\alpha$ ) interleukin (IL)-1, IL-6, IL-17, and IL-23; chemotactic factors (such as macrophage chemoattractant protein-1); and matrix metalloproteinases (MMPs), resulting in bone and cartilage destruction $[9,10]$. Local microenvironmental signals are crucial in macrophage activation having an effect on their plasticity through the promotion of a functional polarisation towards either classically activated (M1) or alternatively activated (M2) phenotype $[7,9,11]$. However, in the modulation of the immune response, M1 and M2 macrophages only appear to be two extremes in the dynamic change of the macrophage phenotype [7, 10-14].

M1 macrophages are defined by the expression of specific surface and cytoplasmatic markers, including Toll-like receptors (i.e. TLR2 and TLR4) and costimulatory molecules (i.e. cluster differentiation CD80 and CD86); they mainly secrete numerous pro-inflammatory cytokines such as TNF $\alpha$, IL-1, and IL-6, which are responsible for joint damage [15-17].

Conversely, M2 macrophages exert anti-inflammatory effects and are phenotypically characterised by the expression of specific surface markers, including macrophage scavenger receptors (CD204 and CD163) and mannose receptor-1 (CD206), in addition to the release of IL-10 and transforming growth factor-b $(\mathrm{TGF}-\beta)[7,11]$.
Interestingly, recent studies have found that the imbalance between M1 and M2 is correlated with the worsening of RA disease $[10,16,18-20]$. In addition, the increase in pro-inflammatory cytokines secreted by M1 macrophages contributes to exacerbate RA flares, whereas the release of anti-inflammatory cytokines mediated by M2 macrophages seems to reverse the inflammatory condition [21].

Wang et al. reported an imbalance in the M1/M2 macrophage ratio in RA patients, confirming a disequilibrium between these two phenotypes and suggesting its potential role in the pathogenesis of RA [16]. Among the molecules that promote macrophage polarisation towards one of the two functional states, some are of interest and need to be mentioned: granulocyte-macrophage colony-stimulating factor (GMCSF), interferon-g (IFN-g), and lipopolysaccharide (LPS) induce the polarisation into a pro-inflammatory M1 phenotype, whereas macrophage colony-stimulating factor (M-CSF), IL-4, IL-10, and IL-13 promote the antiinflammatory M2 phenotype [22-25]. Moreover, it has been demonstrated that anticitrullinated protein antibodies (ACPAs) activate IFN regulatory factor 5 (IRF5) inducing M1 macrophage polarisation, while IRF4 specifically promotes M2 macrophage polarisation [26].

Some studies reported how drugs may contribute to macrophage polarisation [11, 15, 26-28]. Currently, few studies are available on the ability of biological diseasemodifying anti-rheumatic drugs (bDMARDs) to promote the polarisation, and recently, Degboe et al demonstrated the efficacy of anti-TNF $\alpha$ agents in inhibiting in vitro macrophage inflammatory functions and favouring the resolution of inflammation through the polarisation towards alternative macrophage features [29].

Among the other known multiple bDMARDs used in the treatment of RA according to the EULAR guidelines, CTLA4-Ig fusion protein (CTLA4-Ig, abatacept) has proved to modulate the immune response thanks to its innovative pharmacodynamics [30-32]. This fusion protein combines the extracellular domain of the cytotoxic $T$ lymphocyte-associated antigen- 4 with the heavy chain fragment of immunoglobulin $\mathrm{G}$, and it is used to treat several autoimmune inflammatory conditions, including 
RA, psoriatic arthritis, lupus erythematosus, and inflammatory bowel disease [32]. In RA patients who have an inadequate response to biologic DMARDs, CTLA4-Ig was recently observed to reduce the composite score of Disease Activity Score for 28 Joints based on the C-reactive protein level (DAS28/CRP) after 12 weeks of treatment, as well as the DAS28/CRP core components, such as tender joint count and swollen joint count of 28 joints, and the patient's global assessment of disease activity [33]. Moreover, in these RA patients, CTLA4-IG confirmed its higher safety compared to other drugs, such as Janus kinase inhibitors [33]. In a recent study which investigated the histological and transcriptomic effect of CTLA4-Ig on the synovia of active RA patients despite methotrexate, it was observed that the treatment with this fusion protein significantly downregulated both myeloid leukocytes and T cell activation pathways [34].

In an insulin-resistant mouse model, CTLA4-Ig was demonstrated to contribute to the macrophage shift from M1 to M2, reducing adiponectin gene expression and alleviating adipose tissue inflammation through the suppression of TNF $\alpha$ and IL-6 expression [35].

Further observations revealed that the treatment with abatacept of cultured human synovial macrophages drastically reduced their production of pro-inflammatory cytokines, such as IL-1, IL-6, and TNF $\alpha$, interfering with the activation of NF-kB transcription factor and suggesting its possible action directly on antigen-presenting cells, including macrophages themselves [36-38].

Based on these observations, the aim of the present study was to investigate the potential role of CTLA4Ig to promote the shift from M1 to M2 in cultured human M1-polarised monocyte-derived macrophages (M1-MDMs) obtained from healthy subjects (HS) and RA patients, by evaluating the modulation of specific surface and functional markers.

\section{Materials and methods \\ RA patients and $\mathrm{HS}$ enrolment}

Seven RA patients (five females and two males, mean age $54 \pm 13$ years), who fulfilled the 2010 ACR/EULAR Classification Criteria for Rheumatoid Arthritis [39], and ten HS (two females and eight males, mean age $51 \pm 14$ ) were recruited at the Division of Rheumatology, Genova University.

Eligible patients were $\geq 18$ years of age and had adultonset RA for $\geq 3$ months as defined by the 2010 American College of Rheumatology (ACR) criteria [39]. Present and recent constant uses of analgesics, nonsteroidal anti-inflammatory drugs (NSAIDs), low oral corticosteroids dose (less than $5 \mathrm{mg} /$ day prednisone equivalent), and only conventional synthetic csDMARDs (low-dose methotrexate or leflunomide) were permitted for the 7 selected RA patients (Table 1).

All RA patients and HS provided informed consent, and the study was approved by the local ethics committee.

\section{Cell cultures and treatments}

In order to test the most appropriate stimuli to induce the pro-inflammatory condition, cultured human monocytic leukaemia (THP1) cell line and circulating monocytes obtained from HS were activated to macrophages by phorbol myristate acetate (PMA, $5 \mathrm{ng} / \mathrm{mL}$, SigmaAldrich, Milan, Italy) for $24 \mathrm{~h}$ and then treated with LPS $(1 \mathrm{mg} / \mathrm{mL})$ alone or in combination with INF- $\gamma(20$ $\mathrm{ng} / \mathrm{mL}$ ) (Sigma-Aldrich) for $4 \mathrm{~h} \mathrm{[22].} \mathrm{The} \mathrm{quantitative}$ real-time polymerase chain reaction (qRT-PCR) analysis demonstrated a clear reliable acquisition of an M1 inflammatory functional status of cultured THP1-derived macrophages and HS-MDMs, through the upregulation of the gene expression of TLR4, CD80, and CD86 (M1 phenotype markers) together with the downregulation of the gene expression of CD163, CD204, and CD206 (M2 phenotype markers), only after the stimulation with LPS, which therefore was used for the in vitro experiments to induce the M1 phenotype in MDMs (Figs. S1 and S2).

Cultured human monocytes were isolated from peripheral blood mononuclear cells (PBMCs) of HS and RA patients by density gradient centrifugation using FicollPaque (Sigma-Aldrich) and overnight adhesion in tissue culture dishes in the presence of growth medium (RPMI at $10 \%$ of foetal bovine serum, $1 \%$ of penicillin-streptomycin, and 1\% L-glutamine-Euroclone, Milan, Italy).

Cultured HS and RA monocytes were treated with PMA (5 ng/ml, Sigma-Aldrich) for $24 \mathrm{~h}$ to induce their differentiation into MDMs (HS-MDMs and RA-MDMs, respectively). At this step, cultured HS-MDMs were stimulated with LPS (1 mg/mL, Sigma-Aldrich) for 4 $\mathrm{h}$ to induce their polarisation into a pro-inflammatory M1 phenotype (HS-M1-MDMs) [22]. Afterwards, HSM1-MDMs were treated with or without CTLA4-Ig at the concentrations of $100 \mu \mathrm{g} / \mathrm{mL}$ and $500 \mu \mathrm{g} / \mathrm{mL}$ for 3 , 12,24 , and $48 \mathrm{~h}$.

Similarly, cultured RA-MDMs were treated or without CTLA4- $\operatorname{Ig}(100$ and $500 \mu \mathrm{g} / \mathrm{ml})$ for 3, 12, 24, and 48 h. Cultured HSs-MDMs or RA-MDMs maintained in growth medium without any stimulation or treatment were used as unstimulated cells.

Based on our previous in vitro studies using different cell types, such as THP1-derived macrophages and RA synovial macrophages, the best modulatory effect of the treatment with CTLA4-Ig in one single administration on the gene expression was obtained earlier ( 3 and $12 \mathrm{~h}$ ) rather than later on ( 24 and $48 \mathrm{~h})$ [36, 40, 41]. 
Table 1 Demographic and clinical characteristic of the RA patients

\begin{tabular}{|c|c|}
\hline \multicolumn{2}{|l|}{ Demographic characteristics of the RA patients } \\
\hline Age (years, mean \pm SD) & $54 \pm 13$ \\
\hline Sex (female/male) & $4 / 1$ \\
\hline \multicolumn{2}{|l|}{ Autoantibodies and RA patients with hand RX erosions } \\
\hline$+\mathrm{RF}(n / 5=\%)$ & $3(60 \%)$ \\
\hline$+\mathrm{ACPA}(n / 5=\%)$ & $3(60 \%)$ \\
\hline Rx erosions $(n / 5=\%)$ & $3(60 \%)$ \\
\hline Disease duration (years, mean \pm SD) & $6.4 \pm 5$ \\
\hline $0-5$ years $(n / 5=\%)$ & $3(60 \%)$ \\
\hline $5-10$ years $(n / 5=\%)$ & $2(40 \%)$ \\
\hline$>20$ years $(n=\%)$ & $0(0 \%)$ \\
\hline \multicolumn{2}{|l|}{ Comorbidities } \\
\hline Hypertension ( $(n / 5=\%)$ & $3(60 \%)$ \\
\hline Diabetes $(n=\%)$ & $0(0 \%)$ \\
\hline Anaemia $(n=\%)$ & $0(0 \%)$ \\
\hline Sjogren's syndrome $(n=\%)$ & $0(0 \%)$ \\
\hline Heart failure $(n=\%)$ & $0(0 \%)$ \\
\hline Acute cardiac ischemic (ACI) $(n=\%)$ & $0(0 \%)$ \\
\hline Allergic asthma $(n=\%)$ & $0(0 \%)$ \\
\hline Dyslipidaemia $(n / 5=\%)$ & $1(20 \%)$ \\
\hline Neoplasia $(n=\%)$ & $0(0 \%)$ \\
\hline Osteoporosis $(n / 5=\%)$ & $3(60 \%)$ \\
\hline Dysthyroid $(n / 5=\%)$ & $1(20 \%)$ \\
\hline H.pylori $(n=\%)$ & $0(0 \%)$ \\
\hline $\operatorname{HBV}(n=\%)$ & $0(0 \%)$ \\
\hline \multicolumn{2}{|l|}{ NSAID treatment } \\
\hline $\operatorname{NSAIDs}(n / 5=\%)$ & $1(20 \%)$ \\
\hline \multicolumn{2}{|l|}{ Glucocorticoid treatment } \\
\hline Prednisone $(n / 5=\%)$ & $1(20 \%)$ \\
\hline Modified release prednisone ( $n / 5=\%)$ & $2(40 \%)$ \\
\hline \multicolumn{2}{|l|}{ csDMARD treatment } \\
\hline Methotrexate $(n / 5=\%)$ & $3(60 \%)$ \\
\hline Leflunomide (20 mg/day) $(n / 5=\%)$ & $2(30 \%)$ \\
\hline \multicolumn{2}{|l|}{ bDMARD treatment } \\
\hline TNF inhibitors $(n / 5=\%)$ & $1(20 \%)$ \\
\hline Abatacept $(n=\%)$ & $0(0 \%)$ \\
\hline Rituximab $(n=\%)$ & $0(0 \%)$ \\
\hline Tocilizumab $(n=\%)$ & $0(0 \%)$ \\
\hline \multicolumn{2}{|l|}{ Other treatments } \\
\hline Vitamin D $(n / 5=\%)$ & $4(80 \%)$ \\
\hline Folic acid supplementation (5 mg/week) ( $n / 5=\%)$ & $3(60 \%)$ \\
\hline \multicolumn{2}{|l|}{ Clinical score and laboratory findings } \\
\hline $\mathrm{Tj}($ mean \pm SD) & $5 \pm 2.97$ \\
\hline $\mathrm{Sj}($ mean $\pm \mathrm{SD})$ & $1.8 \pm 1.47$ \\
\hline VAS (mean $\pm S D$ ) & $5.2 \pm 2.63$ \\
\hline $\mathrm{CRP}(\mathrm{mg} / \mathrm{dL}$, mean $\pm \mathrm{SD})$ & $11.36 \pm 16.47$ \\
\hline DAS (CRP) (mean \pm SD) & $3.71 \pm 0.56$ \\
\hline
\end{tabular}

$S D$ standard deviation, $R F$ rheumatoid factor, $A C P A$ anticitrullinated protein antibodies, H. pylori Helicobacter pylori, HBV hepatitis B virus, NSAIDs nonsteroidal anti-inflammatory drug, MR prednisone modified release prednisone, cSDMARDs conventional synthetic disease-modifying anti-rheumatic drugs, bDMARDs biological disease-modifying anti-rheumatic drugs, TNF inhibitors tumor necrosis factor inhibitors, $T J$ tender joints, $S J$ swollen joints, VAS visual analogue scale, CRP c-reactive protein, DAS disease activity score

\section{Quantitative real-time polymerase chain reaction (qRT-PCR)}

Total RNA was extracted using the RNA/Protein Purification Plus Kit (Norgen Biotek Corp., Canada) or Nucleospin RNA/Protein kit (Macherey Nagel, Germany) based on the number of cultured cells. The RNA was quantified by Nanodrop (Thermo Fisher Scientific, MA, USA) which also allowed the evaluation of RNA integrity, and retrotranscribed (until $3 \mu \mathrm{g}$ ) using Quantitec reverse transcription kit (QIAGEN, Netherlands) to obtain cDNA. The cDNA was amplified in a real-time experiment with Eppendorf Realplex 4 Mastercycler (Hamburg, Germany).

In order to select the most appropriate and stable housekeeping (HK) gene, four potential HK genes were selected: glyceraldehyde 3-phosphate dehydrogenase (GAPDH, NM_001256799.3), beta (b)-Actin (NM_001101.5), human ubiquitin-conjugated enzyme E2D2 (hUBE2D2, NM_003339.3), and ribosomal protein L13A (RPL13A, NM_012423.4) [42]. The stability of the chosen HK genes was determined in preliminary experiments in cultured THP1-derived macrophages reporting no significant variance, as well as in M1-MDMs, where the hUBE2D2 gene showed the best integrity and higher primer efficiency.

The gene expression of M1 macrophage markers (CD80, CD86 and TLR4), surface M2 macrophage markers (CD206, CD204, CD163), and a functional M2 marker proto-oncogene tyrosine-protein kinase MER (MerTK) was investigated using the following primers: CD80 = NM_005191, CD86 = NM_001206924, TLR4 = NM_003266, CD206 = NM_002438, CD204 = NM_001363744, CD163 = NM_001370145, and MerTK = NM_006343.3. Relative quantification of gene expression was performed using the $2^{-\Delta \Delta C T}$ method [43]. The melting curve was included in all qRT-PCR assays to confirm the specificity of the SYBR green assay.

\section{Western blotting}

Proteins were extracted in ice using radio-immunoprecipitation assay (RIPA) buffer: tris(hydroxymethyl) aminomethane-hydrochloric acid [TrisHCl] $\mathrm{pH} 7.425$ $\mathrm{mM}$, sodium chloride $\left[\mathrm{NaCl}_{2}\right] 150 \mathrm{mM}$, Triton X-100 1\%, sodium dodecyl sulphate [SDS] $0.1 \%$, ethylene glycolbis( $\beta$-aminoethyl ether)-N,N, $\mathrm{N}^{\prime}, \mathrm{N}^{\prime}$-tetraacetic acid [EGTA] and ethylenediaminetetraacetic acid [EDTA] 1 $\mathrm{mM}$, and $1 \times$ protease inhibitors [sodium orthovanadate $\left(\mathrm{Na}_{3} \mathrm{VO}_{4}\right)$, phenylmethylsulphonyl fluoride (PMSF), leupeptin, aprotinin; Sigma-Aldrich]. Proteins were quantified by the bicinchoninic acid (BCA) method.

For Western blotting assays, $60 \mu \mathrm{g}$ of proteins was separated by electrophoresis on $4-12 \%$ gradient Tris-glycine 
gels (GenScript, NY, USA) and then transferred onto a Hybond-C-nitrocellulose membrane (Thermo Fisher Scientific).

After $1 \mathrm{~h}$ in blocking solution (PBS $1 \times$ and $0.1 \%$ Triton $\mathrm{X}-100)$ at $5 \%$ of non-fat powdered milk or $5 \%$ of bovine serum albumin (BSA), the membranes were incubated overnight at $4{ }^{\circ} \mathrm{C}$ with the primary antibodies anti-human CD204 (dilution 1:500; Abcam, Cambridge, UK), CD163, and CD206 (dilution 1:500; Cell Signalling Technology, Danvers, MA, USA).

The membranes were subsequently incubated with the following horseradish peroxidase (HRP)-conjugated secondary antibodies: anti-mouse IgG for CD204, antirabbit IgG for CD206, and CD163 (dilution 1:2000; Cell Signalling Technology).

The membranes were also incubated with primary HRP-conjugated antibodies to human GAPDH or $\beta$-actin (dilution 1:1000 and 1:2000, respectively; Santa Cruz Biotechnology, Dallas, USA) to confirm similar loading of protein samples and the efficacy of the electrophoretic transfer.

Protein synthesis was detected using the enhanced chemiluminescence system (SuperSignal $^{\mathrm{TM}}$ West Femto Maximum Sensitivity Substrate, Thermo Fisher Scientific), and the related densitometric analysis was performed with the Uvitec Image Analysis System (Uvitec, Cambridge, UK). Western blotting was performed for each independent in vitro experiment with cultured M1-MDMs and RA-MDMs.

For each experimental condition, the value of the synthesis of CD204, CD206, CD163, TLR4, CD80, and CD86 was normalised to that of the corresponding GAPDH or $\beta$-actin. The resulting value of each treatment was compared with that of the related untreated cells (taken as unit value).

\section{Statistical analysis}

The statistical analysis was carried out with GraphPad Prism (version 8.4.0, GraphPad Software, San Diego, CA, USA). Differences in continuous unpaired variables were tested using non-parametric Mann-Whitney $U$-test and Wilcoxon test for continuous paired variables. Any $p$-value lower than 0.05 was considered as statistically significant. The results of qRT-PCR and Western blotting are reported as mean \pm standard deviation (SD).

The Spearman rank non-parametric correlation test was performed to investigate whether the downregulated gene expression of M1 markers or the upregulated gene and protein expression of M2 markers (dependent variable) and CTLA4-Ig dosage (independent variable) were related. To know the correlation strength, we use the following guideline: $-0.3 \leq$ rho $\leq 0 / 0 \leq$ rho $\leq+0.3$ : "weak" association; $-0.3 \leq$ rho $\leq-0.7 /+0.3 \leq$ rho $\leq$
+0.7 : "moderate" association; and $-0.7 \leq$ rho $\leq-1 /+$ $0.7 \leq$ rho $\leq+1$ : "strong" association [44]. The more the rho's value is close to +1 or -1 , the more the association is considered monotonic $[44,45]$.

\section{Results \\ Abatacept significantly downregulated the TLR4, CD80, and CD86 M1 markers and upregulated the CD163, CD204, and CD206 M2 markers in cultured HS-M1-MDMs}

The stimulation with LPS induced cultured HS-MDMs to acquire an M1 macrophage phenotype (HS-M1-MDMs) through the upregulation of the gene expression of all the investigated M1 markers compared to unstimulated cells; this upregulation was significant for TLR4 and CD80 already after $3 \mathrm{~h}$ of stimulation $(p<0.01$ for both markers; CD86 $p=0.18$; Fig. 1A). The gene expression of all these M1 phenotype markers was maintained significantly upregulated by LPS also after $12 \mathrm{~h}$ of stimulation $(p<0.05$ for TLR4, $p<0.01$ for CD80 and CD86 vs. unstimulated cells; Fig. 1A). At the same time, LPS significantly downregulated the gene expression of all M2 phenotype markers compared to unstimulated MDMs (CD163: $p<0.01$ at $3 \mathrm{~h}$ and $p<0.05$ at $12 \mathrm{~h}$; CD204: $p<$ 0.05 both at 3 and 12 h; CD206: $p<0.01$ at 3 h; Fig. 1B).

In cultured HS-M1-MDMs, CTLA4-Ig treatment at the concentrations of $100 \mu \mathrm{M}$ and $500 \mu \mathrm{M}$ significantly reduced the upregulation of the gene expression of all M1 markers induced by LPS already after $3 \mathrm{~h}$ of treatment (TLR4, CD80, CD86: $p<0.01$ vs. untreated HS-M1-MDMs for both concentrations; Fig. 1A). The downregulatory effect of CTLA4-Ig treatment on the gene expression of M1 markers was maintained significant also after $12 \mathrm{~h}$ of treatment for TLR4 and CD86 compared to untreated HS-M1-MDMs $(p<0.05$ for both concentrations; Fig. 1A).

Of note, in cultured HS-M1-MDMs, CTLA4-Ig (100 $\mu \mathrm{M}$ and $500 \mu \mathrm{M})$ upregulated the gene expression of all the investigated M2 markers after 3 and $12 \mathrm{~h}$ of treatment (Fig. 1B). In detail, CTLA4-Ig $100 \mu \mathrm{M}$ upregulated the gene expression of CD163 and CD204 but significantly only that of CD206 after $3 \mathrm{~h}$ of treatment ( $p<0.01$ vs. untreated HS-M1-MDMs; Fig. 1B). Noteworthy, the gene expression of all these M2 phenotype markers was significantly increased by CTLA4-Ig $100 \mu \mathrm{M}$ after $12 \mathrm{~h}$ of treatment $(p<0.01$ for CD163, $p<0.05$ for CD204 and CD206 vs. untreated HS-M1-MDMs; Fig. 1B). Instead, CTLA4Ig $500 \mu \mathrm{M}$ significantly upregulated the gene expression of all the investigated M2 phenotype markers in cultured HS-M1-MDMs already after $3 \mathrm{~h}$ of treatment $(p<0.05$ for CD163 and CD204; $p<0.01$ for CD206 vs. untreated HS-M1-MDMs; Fig. 1B). The increased gene expression of CD163 and CD206 was maintained statistically significant by CTLA4-Ig $500 \mu \mathrm{M}$ after $12 \mathrm{~h}$ of treatment, 


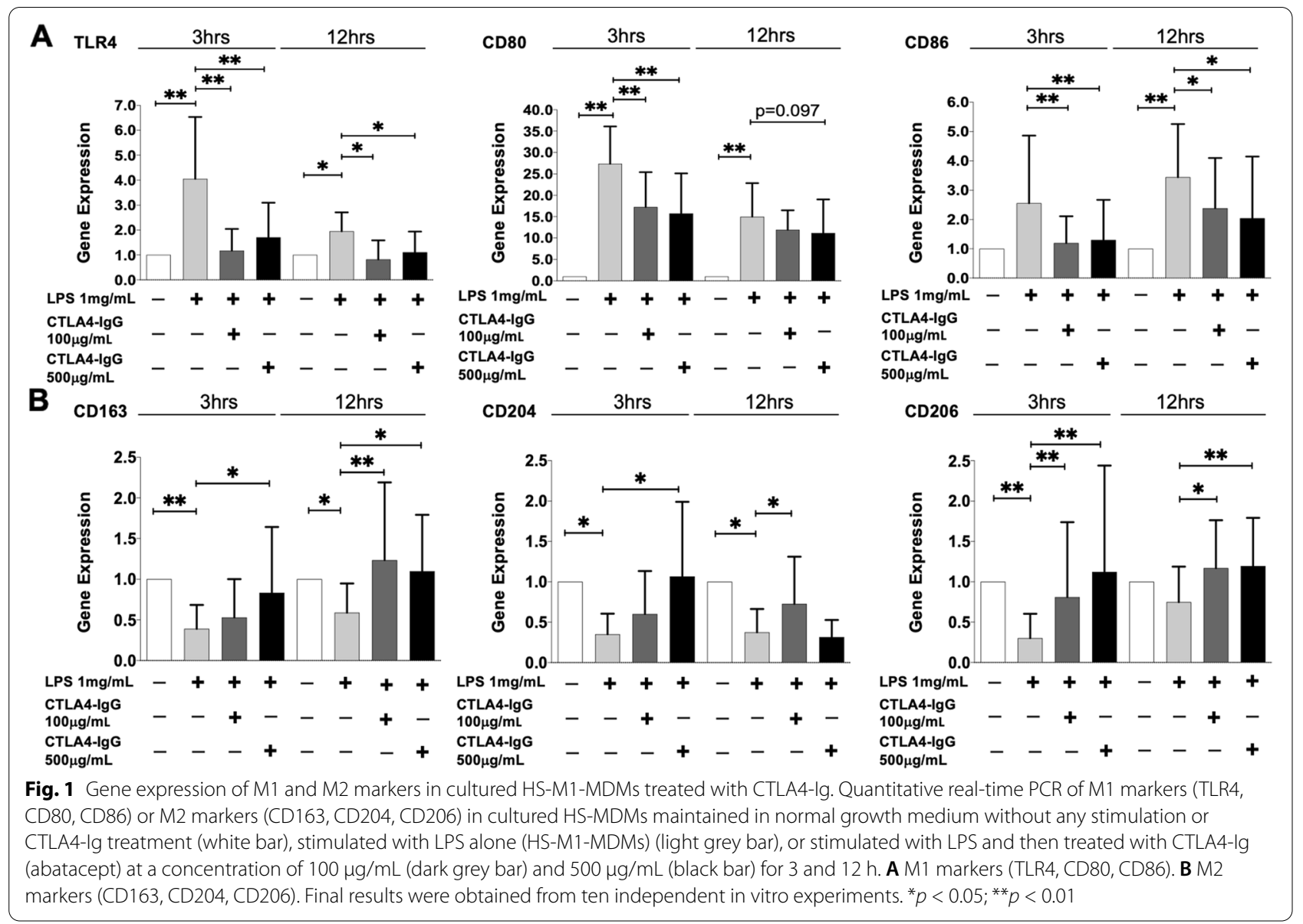

compared to cultured untreated HS-M1-MDMs $(p<0.05$ and $p<0.01$, respectively; Fig. 1B).

In cultured HS-M1-MDMs, the modulation of these M2 phenotype markers was investigated also at the protein level.

LPS determined a slight decrease (not significant) in the synthesis of CD163, CD204, and CD206 after 24 h of stimulation compared to unstimulated cells; interestingly, a statistically significant reduction of CD163 after $48 \mathrm{~h}$ of stimulation was observed, suggesting a lag time for the protein synthesis ( $p<0.05$; Fig. 2).

Noteworthy, in cultured HS-M1-MDMs, both concentrations of CTLA4-Ig significantly blocked the LPSinduced decrease in CD163 and CD204 protein synthesis after $24 \mathrm{~h}$ of treatment, promoting an increase in their synthesis ( $p<0.05$ vs. untreated HS-M1-MDMs; Fig. 2). The synthesis of CD206 seems not to be further significantly modulated by the treatment with CTLA4-Ig (Fig. 2).

However, after $48 \mathrm{~h}$ of treatment, CTLA4-Ig significantly increased the protein synthesis of all the investigated M2 phenotype markers compared to untreated
HS-M1-MDMs but limited to the high tested concentration ( $p<0.05$; Fig. 2$)$.

To determine whether in cultured HS-M1-MDMs the effect of CTLA4-Ig was dose-dependent, the Spearman rank non-parametric correlation test was used. In cultured HS-M1-MDMs, the gene expression of TLR4 and CD80 after $3 \mathrm{~h}$ of treatment showed a "moderate" and statistically significant negative association with the CTLA4-Ig dosage as well as that of TLR4 and CD86 after $12 \mathrm{~h}$ of treatment (Table $2 \mathrm{~A}$ ). As for the M2 markers, a statistically significant "strong" association between the dose-dependent effect of CTLA4-Ig and the gene expression of CD204 after $3 \mathrm{~h}$ of treatment was observed (rho = 0.72, $p<0.0001$; Table 2 A). As for CD163 and CD206, a "weak" association (not significant) after $3 \mathrm{~h}$ and a significant "moderate" association after $12 \mathrm{~h}$ of treatment were found (Table $2 \mathrm{~A}$ ). The results concerning the protein synthesis showed a "moderate" and statistically significant association for CD204 and CD163 after $24 \mathrm{~h}$ of treatment (Table $2 \mathrm{~A}$ ). Furthermore, after $48 \mathrm{~h}$ of treatment, all M2 markers indicate a "moderate" statistically significant association with CTLA4-Ig dosage (Table $2 \mathrm{~A}$ ). 


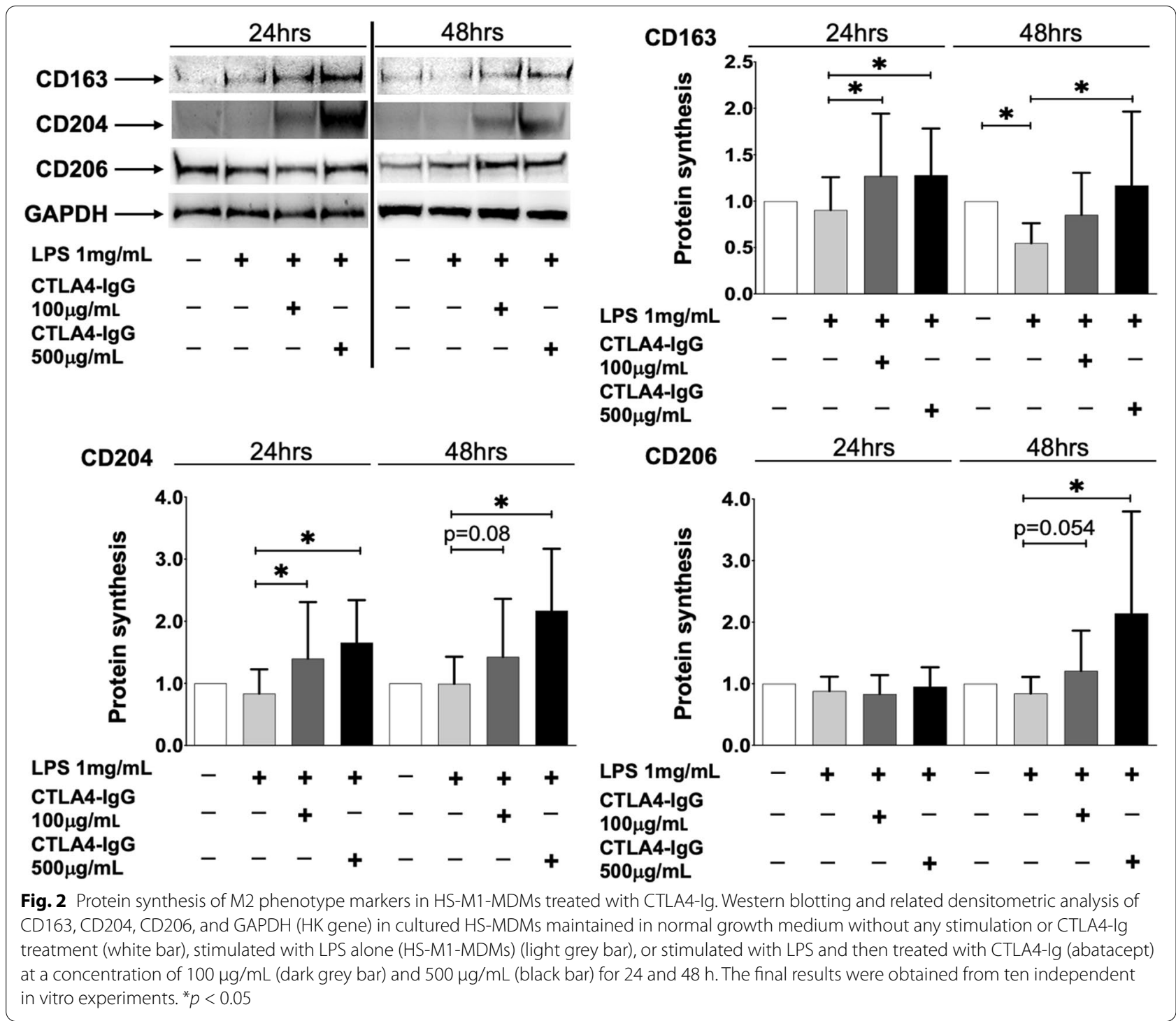

\section{Abatacept significantly downregulated the TLR4 and CD80 $M 1$ markers and upregulated the M2 marker in cultured RA-MDMs}

The effect of the treatment with CTLA4-Ig in inducing an M2 phenotype was also investigated in cultured MDMs obtained from RA patients.

The preliminary results showed that cultured RAMDMs were characterised by a higher basal gene expression of TLR4, CD80, and CD86 compared to cultured untreated HS-MDMs, confirming their activated M1 phenotype (Fig. S4). Based on these data, cultured RA-MDMs were not stimulated with LPS to further induce the pro-inflammatory M1 phenotype (already existing), but they were directly treated with CTLA4-Ig at the concentrations of $100 \mu \mathrm{M}$ and $500 \mu \mathrm{M}$.
Therefore, in these cultured RA-MDMs, the treatment with both concentrations of CTLA4-Ig downregulated all the investigated M1 markers at both timings (Fig. 3A). Of note, CTLA4-Ig $100 \mu \mathrm{g} / \mathrm{mL}$ downregulated the gene expression of TLR4, CD86, and significantly the one of CD80 after $3 \mathrm{~h}$ of treatment compared to unstimulated RA-MDMs (CD80: $p<0.05$ ), whereas the high tested concentration of CTLA4-Ig downregulated the gene expression of all M1 markers, but not in a statistically significant manner ( $p=0.06$ for all M1 markers) (Fig. 3A). Both concentrations of CTLA4-Ig significantly downregulated the gene expression of all tested M1 markers after $12 \mathrm{~h}$ of treatment compared to unstimulated RAMDMs $(p<0.05$ for all markers and for both concentrations; Fig. 3A). At the same time, the treatment with 
Table 2 -values of the gene expression of M1 and M2 markers in cultured HS-M1-MDMS and RA-MDMs and correlation statistical testing

Table II A.

\begin{tabular}{|c|c|c|c|c|c|c|c|c|c|}
\hline \multirow[b]{2}{*}{ Experiment } & \multirow[b]{2}{*}{ Time } & \multirow[b]{2}{*}{ MARKER } & \multicolumn{3}{|c|}{ Group (median [min-max]) } & \multirow{2}{*}{$\begin{array}{c}\text { CTLA4-Ig (100 } \\
\mu \mathrm{g} / \mathrm{mL}) \text { Vs } \\
\text { CTLA4-lg (500 } \\
\mu \mathrm{g} / \mathrm{mL}) \mathrm{p}\end{array}$} & \multirow[b]{2}{*}{$\begin{array}{c}\text { CTLA4-lg } \\
(100 \mu \mathrm{g} / \mathrm{mL}) \\
\text { Vs LPS } \\
1 \mathrm{mg} / \mathrm{mL} \mathrm{p}\end{array}$} & \multirow[b]{2}{*}{$\begin{array}{l}\text { CTLA4-lg } \\
(500 \mu \mathrm{g} / \mathrm{mL}) \\
\text { Vs LPS } 1 \\
\mathrm{mg} / \mathrm{mL} \text { p }\end{array}$} & \multirow[b]{2}{*}{ Dose-effect correlation } \\
\hline & & & $\begin{array}{l}\text { LPS } 1(\mathrm{mg} / \mathrm{mL}) \\
\text { vs. } \\
\text { unstimulated } \\
\text { cells }\end{array}$ & $\begin{array}{l}\text { CTLA4-Ig (100 } \\
\mu \mathrm{g} / \mathrm{mL}) \text { vs. } \\
\text { unstimulated } \\
\text { cells }\end{array}$ & $\begin{array}{l}\text { CTLA4-Ig (500 } \\
\mu \mathrm{g} / \mathrm{mL}) \text { vs. } \\
\text { unstimulated } \\
\text { cells }\end{array}$ & & & & \\
\hline \multirow{12}{*}{$\begin{array}{l}\text { HS-M1- } \\
\text { MDMs } \\
\text { (gene } \\
\text { expression) }\end{array}$} & \multirow{6}{*}{ 3hrs } & TLR4 & $3.85[1.01-8.3]$ & $1.06[0.02-2.6]$ & $1.1[0.3-3.9]$ & 0.074 & 0.0039 & 0.0039 & rho $=-0.47 ; p=0.0093$ \\
\hline & & CD80 & $25.03[16.9-45.6]$ & $18.9[0.7-30.9]$ & $15.6[0.6-33.0]$ & 0.131 & 0.0039 & 0.002 & $\mathrm{rho}=-0.51 ; p=0.0038$ \\
\hline & & CD86 & $1.14[0.52-6.0]$ & $0.8[0.4-3.0]$ & $0.8[0.3-4.7]$ & 0.865 & 0.002 & 0.002 & rho $=-0.34 ; p=0.0683$ \\
\hline & & CD163 & $0.32[0.1-0.9]$ & $0.36[0.12-1.34]$ & $0.53[0.11-2.3]$ & 0.375 & 0.4688 & 0.0781 & $\mathrm{rho}=0.32 ; \mathrm{p}=0.0886$ \\
\hline & & CD204 & $0.37[0.005-0.76]$ & $0.57[0.003-1.6]$ & $0.71[0.6-3.0]$ & 0.313 & 0.1562 & 0.0312 & rho $=0.72 ; p=<0.0001$ \\
\hline & & CD206 & $0.2[0.05-1.1]$ & $0.4[0.13-3.03]$ & $0.54[0.15-4.5]$ & 0.697 & 0.002 & 0.0059 & rho $=0.35 ; p=0.0623$ \\
\hline & \multirow{6}{*}{$12 \mathrm{hrs}$} & TLR4 & $1.8[1.06-2.9]$ & $0.6[0.2-2.3]$ & $0.91[0.5-2.7]$ & 0.156 & 0.0312 & 0.0312 & rho $=-0.43 ; p=0.072$ \\
\hline & & CD80 & $13.5[5.5-29.8]$ & $10.3[7.15-21.4]$ & $6.9[4.5-25.5]$ & 0.570 & 0.1055 & 0.0977 & rho $=-0.29 ; p=0.1168$ \\
\hline & & CD86 & $2.31[1.2-5.6]$ & $2.7[0.25-4.6]$ & $1.01[0.22-5.9]$ & 0.383 & 0.0195 & 0.0195 & rho $=-0.36 ; p=0.0501$ \\
\hline & & CD163 & $0.52[0.1-1.1]$ & $1.06[0.22-3.2]$ & $0.99[0.12-2.6]$ & 0.742 & 0.0078 & 0.0234 & rho $=0.4 ; p=0.0301$ \\
\hline & & CD204 & $0.33[0.01-0.8]$ & $0.5[0.07-1.6]$ & $0.3[0.09-0.74]$ & 0.031 & 0.0156 & 0.8521 & rho $=-0.18 ; p=0.3298$ \\
\hline & & CD206 & $0.62[0.02-1.4]$ & $1.17[0.06-1.8]$ & $1.35[0.09-1.9]$ & 0.82 & 0.0117 & 0.078 & rho $=0.44 ; p=0.0141$ \\
\hline \multirow{6}{*}{$\begin{array}{l}\text { HS-M1- } \\
\text { MDMs } \\
\text { (protein } \\
\text { synthesis) }\end{array}$} & \multirow{3}{*}{ 24hrs } & CD163 & $0.92[0.3-1.4]$ & $1.1[0.5-2.3]$ & $1.21[0.65-2.2]$ & $>0.9999$ & 0.0234 & 0.0391 & rho $=0.35 ; p=0.0551$ \\
\hline & & CD204 & $0.75[0.3-1.6]$ & $1.12[0.5-3.0]$ & $1.85[0.66-2.4]$ & 0.2969 & 0.0312 & 0.0156 & rho $=0.55 ; p=0.0015$ \\
\hline & & CD206 & $0.85[0.7-1.3]$ & $0.82[0.52-1.2]$ & $0.8[0.7-1.4]$ & 0.4375 & 0.4375 & 0.4375 & rho $=0.095 ; p=0.6188$ \\
\hline & \multirow{3}{*}{ 48hrs } & CD163 & $0.51[0.3-0.9]$ & $0.76[0.34-1.7]$ & $0.94[0.5-2.8]$ & 0.2969 & 0.1094 & 0.0156 & rho $=0.59 ; p=0.0006$ \\
\hline & & CD204 & $0.91[0.5-1.6]$ & $1.07[0.7-3.3]$ & $2.1[0.97-3.8]$ & 0.0977 & 0.0742 & 0.0391 & rho $=0.55 ; p=0.0016$ \\
\hline & & CD206 & $0.82[0.4-1.2]$ & $1.16[0.26-2.6]$ & $2.07[0.107-5.58]$ & 0.0781 & 0.0547 & 0.0234 & $\mathrm{rho}=0.57 ; p=0.0014$ \\
\hline
\end{tabular}

Table II B.

\begin{tabular}{|c|c|c|c|c|c|c|c|c|}
\hline \multirow[b]{2}{*}{ Experiment } & \multirow[b]{2}{*}{ Time } & \multirow[b]{2}{*}{ MARKER } & \multicolumn{2}{|c|}{ Group (median [min-max]) } & \multirow[b]{2}{*}{$\begin{array}{l}\text { CTLA4-Ig (100 } \\
\mu \mathrm{g} / \mathrm{mL}) \text { Vs CTLA4- } \\
\lg (500 \mu \mathrm{g} / \mathrm{mL}) \mathrm{p}\end{array}$} & \multirow{2}{*}{$\begin{array}{c}\text { CTLA4-lg } \\
(100 \mu \mathrm{g} / \mathrm{mL}) \\
\text { Vs } \\
\text { unstimulated } \\
\text { MDMs p }\end{array}$} & \multirow{2}{*}{$\begin{array}{c}\text { CTLA4-lg } \\
(500 \mu g / m L) \\
\text { Vs } \\
\text { unstimulated } \\
\text { MDMs p }\end{array}$} & \multirow[b]{2}{*}{ Dose-effect correlation } \\
\hline & & & $\begin{array}{c}\text { CTLA4-lg (100 } \\
\mu \mathrm{g} / \mathrm{mL}) \text { vs. } \\
\text { unstimulated } \\
\text { cells }\end{array}$ & $\begin{array}{c}\text { CTLA4-Ig (500 } \\
\mu \mathrm{g} / \mathrm{mL} \text { ) vs. } \\
\text { unstimulated } \\
\text { cells }\end{array}$ & & & & \\
\hline \multirow{14}{*}{$\begin{array}{l}\text { RA-MDMs } \\
\text { (gene } \\
\text { expression) }\end{array}$} & \multirow{7}{*}{$3 \mathrm{hrs}$} & TLR4 & $0.5[0.06-1.1]$ & $0.32[0.0001-0.74]$ & 0.125 & 0.125 & 0.0625 & rho $=-0.73 ; p=0.0002$ \\
\hline & & CD80 & $0.6[0.02-0.9]$ & $0.7[0.4-1.01]$ & 0.0312 & 0.0312 & 0.0625 & rho $=-0.47 ; p=0.031$ \\
\hline & & CD86 & $0.84[0.82-0.92]$ & $0.7[0.18-0.8]$ & 0.0625 & 0.0625 & 0.0625 & rho $=-0.96 ; p=<0.0001$ \\
\hline & & CD163 & $3.12[1.31-3.82]$ & $3.08[0.45-13.6]$ & $>0.99999$ & 0.0312 & 0.0938 & rho $=0.63 ; p=0.0023$ \\
\hline & & CD204 & $1.04[0.82-3.2]$ & $1.08[0.95-2.3]$ & 0.9375 & 0.0859 & 0.0391 & rho $=0.53 ; p=0.0144$ \\
\hline & & CD206 & $1.54[0.95-4.6]$ & $2.04[0.9-4.6]$ & 0.0625 & 0.0156 & 0.0156 & rho $=0.33 ; p=0.1392$ \\
\hline & & MerTk & $0.75[0.24-1.08]$ & $1.45[0.7-2.24]$ & 0.0625 & 0.0938 & 0.2031 & rho $=0.53 ; p=0.0144$ \\
\hline & \multirow{7}{*}{$12 \mathrm{hrs}$} & TLR4 & $0.9[0.44-1.1]$ & $0.7[0.4-0.9]$ & 0.2969 & 0.0469 & 0.0156 & rho $=-0.74 ; p=0.004$ \\
\hline & & CD80 & $0.45[0.002-1.07]$ & $0.4[0.09-0.9]$ & 0.8125 & 0.0312 & 0.0156 & rho $=-0.63 ; p=0.0023$ \\
\hline & & CD86 & $0.69[0.5-1.1]$ & $0.74[0.2-1.2]$ & 0.9375 & 0.0312 & 0.0469 & rho $=-0.48 ; p=0.0256$ \\
\hline & & CD163 & $3.35[1.4-11.5]$ & $2.1[1.4-11.0]$ & 0.5669 & 0.0156 & 0.0156 & rho $=0.48 ; p=0.0434$ \\
\hline & & CD204 & $1.2[0.64-6.8]$ & $1.32[0.97-2.85]$ & 0.6562 & 0.3438 & 0.0312 & rho $=0.44 ; p=0.0477$ \\
\hline & & CD206 & $1.2[0.24-5.2]$ & $2.4[1.4-4.9]$ & 0.1875 & 0.2188 & 0.0312 & rho $=0.5 ; p=0.0209$ \\
\hline & & MerTk & $1.37[1.27-2.38]$ & $1.78[1.69-2.68]$ & 0.0312 & 0.0312 & 0.0312 & $\mathrm{rho}=0.43 ; p=0.0531$ \\
\hline \multirow{6}{*}{$\begin{array}{l}\text { RA-MDMs } \\
\text { (protein } \\
\text { synthesis) }\end{array}$} & \multirow{3}{*}{$24 \mathrm{hrs}$} & CD163 & $1.23[0.5-1.84]$ & $1.06[0.28-1.68]$ & 0.8125 & 0.4844 & $>0.99999$ & rho $=0.059 ; p=0.7996$ \\
\hline & & CD204 & $1.3[1.09-2.4]$ & $2.7[1.98-6.2]$ & 0.0312 & 0.0312 & 0.0312 & rho $=0.94 ; p=<0.0001$ \\
\hline & & CD206 & $1.6[0.98-2.24]$ & $1.12[1.1-2.3]$ & 0.8438 & 0.0625 & 0.0312 & rho $=0.62 ; p=0.019$ \\
\hline & \multirow{3}{*}{ 48hrs } & CD163 & $0.79[0.54-1.28]$ & $0.34[0.25-1.66]$ & 0.1875 & 0.625 & 0.1875 & rho $=-0.48 ; p=0.077$ \\
\hline & & CD204 & $1.34[0.83-2.06]$ & $1.92[1.65-3.4]$ & 0.0625 & 0.125 & 0.0625 & rho $=0.5215 ; p=0.026$ \\
\hline & & CD206 & $1.3[0.6-1.8]$ & $0.5[0.3-1.7]$ & 0.0625 & 0.5312 & 0.5 & rho $=-0.17 ; p=0.5543$ \\
\hline
\end{tabular}

The median (with range) of the gene expression and protein synthesis of M1 (TLR4, CD80, CD86) and M2 markers (CD163, CD204, CD206, MerTK) (A) in cultured HS-M1-MDMs and (B) in cultured RA-MDMs. In the white part of Table 2A, the gene expression and the protein synthesis correspond respectively to the expression and protein level (fold increase) of the target (gene or protein) in cultured HS-MDMs stimulated with LPS alone and stimulated with LPS followed by treatment with CTLA4-Ig compared with that of unstimulated HS-MDMs taken as the unit value by definition [43]. In the white part of Table 2 B, the gene expression and the protein synthesis correspond respectively to the expression and protein level (fold increase) of the target (gene or protein) in cultured CTLA4-Ig-treated RA-MDMs compared with that of untreated RA-MDMs taken as the unit value by definition [43]. In the light grey part of Table $2 \mathrm{~A}$ and $\mathrm{B}$, the $p$-values related to the comparison between the experimental conditions and those related to the Spearman rank non-parametric correlation test were reported 


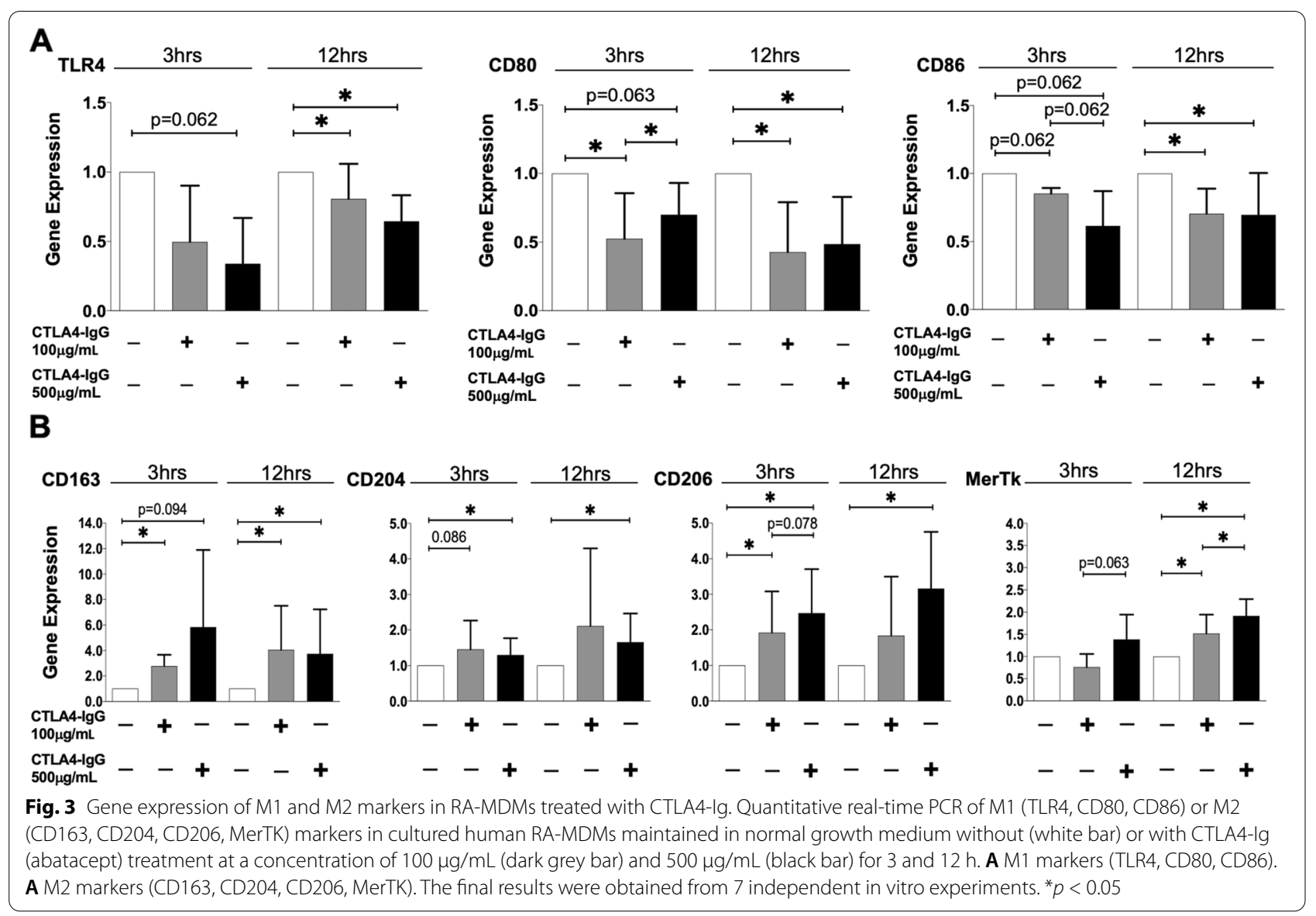

CTLA4-Ig induced an upregulation of the gene expression of all the surface M2 markers CD163, CD204, and CD206 (Fig. 3B). In particular, CTLA4-Ig $100 \mu \mathrm{g} / \mathrm{mL}$ significantly upregulated the gene expression of CD163 and CD206 after $3 \mathrm{~h}$ of treatment compared to unstimulated RA-MDMs ( $p<0.05$; Fig. 3B). The CD163 gene expression was maintained significantly increased by CTLA4Ig $100 \mu \mathrm{g} / \mathrm{mL}$ also after $12 \mathrm{~h}$ of treatment $(p<0.05 \mathrm{vs}$. unstimulated cells; Fig. 3B). The high concentration of CTLA4-Ig upregulated the gene expression of CD204 and CD206 after both 3 and $12 \mathrm{~h}$ of treatment and that of CD163 only after $12 \mathrm{~h}$ of treatment compared to unstimulated RA-MDMs (CD204 and CD206: $p<0.05$ at both 3 and $12 \mathrm{~h}$; CD163: $p<0.05$ at $12 \mathrm{~h}$; Fig 3B).

In addition to the evaluation of surface M2 markers, the capability of CTLA4-Ig treatment to induce the upregulation of the gene expression of MerTK, a functional M2 marker relevant in RA pathogenesis, was also investigated in cultured RA-MDMs. In these cultured cells, both concentrations of CTLA4-Ig induced a significant upregulation of MerTK gene expression compared to unstimulated RA-MDMs, primarily after $12 \mathrm{~h}$ of treatment ( $p<0.05$ for both concentrations; Fig. 3B).
At the protein level, in cultured RA-MDMs, CTLA4Ig $100 \mu \mathrm{g} / \mathrm{mL}$ slightly increased the synthesis of CD163 after $24 \mathrm{~h}$ of treatment, whereas the high concentration did not induce any upregulation of this M2 phenotype marker, even after $48 \mathrm{~h}$ of treatment compared to unstimulated cells (Fig. 4). Nonetheless, both concentrations of CTLA4-Ig induced a significant increase in the synthesis of CD204, primarily after $24 \mathrm{~h}$ of treatment compared to unstimulated RA-MDMs $(p<0.05$ for both concentrations; Fig. 4). Moreover, CTLA4-Ig induced an increase in CD206 protein synthesis after $24 \mathrm{~h}$ of treatment, which was significant after treatment with the high concentration ( $p<0.05$ vs. unstimulated RA-MDMs; Fig. 4).

However, in cultured RA-MDMs, the Spearman non-parametric correlation test showed a significant "strong" negative association between the increase of the CTLA4-Ig dosage and the downregulation of the gene expression of TLR 4 after 3 and $12 \mathrm{~h}$ of treatment and CD86 after $3 \mathrm{~h}$ of treatment (TLR4 rho $=-0.73$, $p=0.0002$; CD86 rho $=-0.96, p<0.0001$ after $3 \mathrm{~h}$; TLR4 rho $=-0.74 ; p=0.004$ after $12 \mathrm{~h}$ ), whereas the gene expression of CD80 (after 3 and $12 \mathrm{~h}$ of treatment) and CD86 (after $12 \mathrm{~h}$ of treatment) showed a significant 


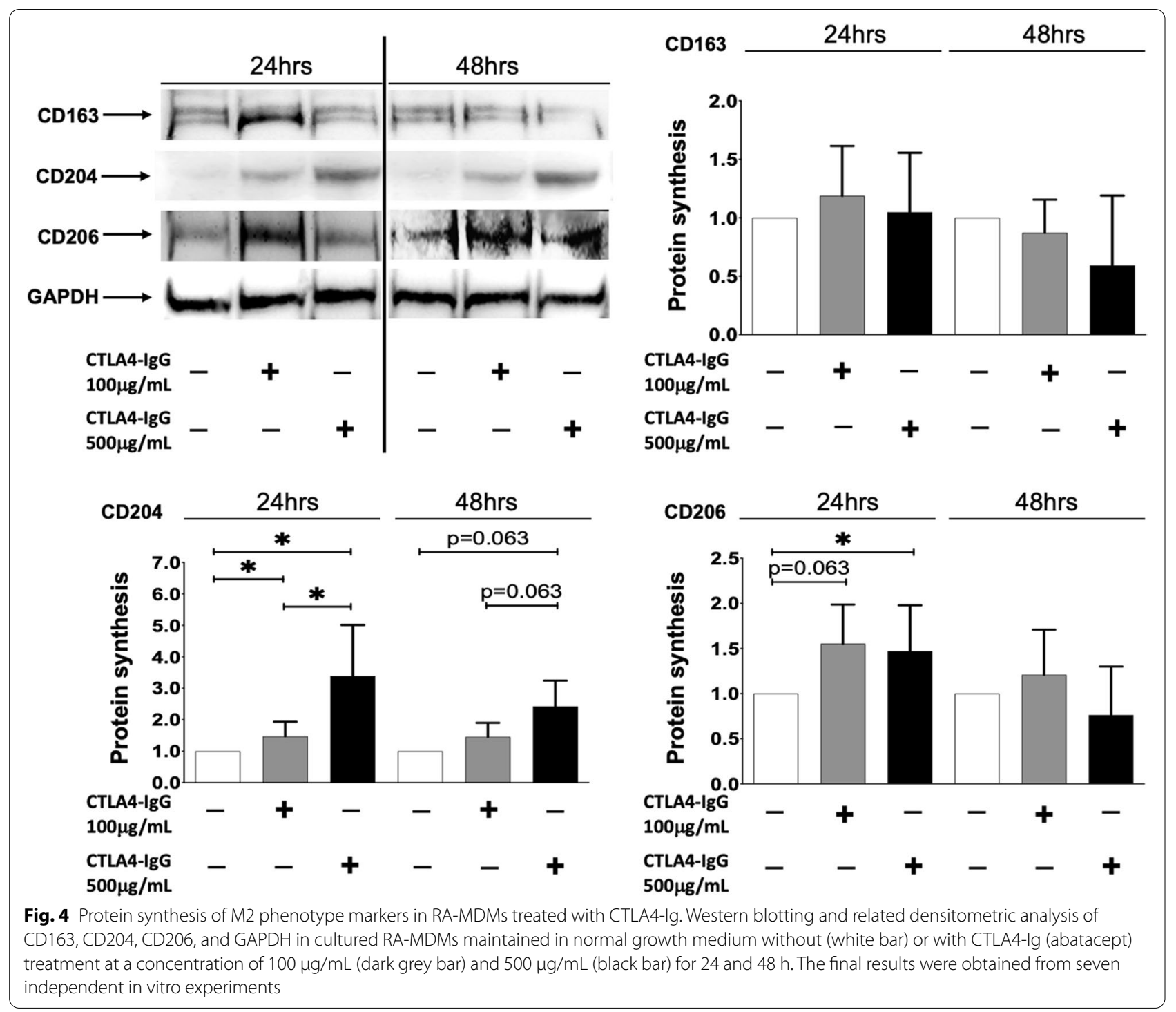

"moderate" association with CTLA4-Ig dosage. In addition, the gene expression of all the M2 markers showed a significant "moderate" positive association with the dosage of CTLA4-Ig (Table 2 B). At the protein level, a significant "strong"/"moderate" (CD204 and CD206) positive association with CTLA4-Ig dosage was observed after $24 \mathrm{~h}$ of treatment $(\mathrm{CD} 204$ rho $=0.94, p$ $<0.0001$; Table 2 B).

\section{Discussion}

The results of the present study show that CTLA4-Ig treatment seems to promote the shift into an M2 phenotype of both cultured HS-M1-MDMs polarised by LPS stimulation and cultured MDMs obtained from RA patients. This shift was detected by the downregulation of the gene expression of M1 phenotype markers (TLR4, CD80, CD86) along with the upregulation of the gene expression of M2 phenotype markers (CD163, CD204, CD206) and their related protein synthesis. Of note, together with the upregulation of specific surface markers of M2 phenotype, the effect of CTLA4-Ig treatment in promoting the M1-M2 shift was observed also at the functional level, through the upregulation of gene expression of MerTK, which seems to play important functions potentially relevant in RA, as recently described [46].

In the pathogenesis of RA and joint damage, monocytes/macrophages are considered to play a central role, including newly differentiated peripheral blood monocytes, compared to fibroblasts, lymphocytes and 
neutrophils, which cooperate with different functions [7]. In fact, macrophages generate an inflammatory milieu by producing pro-inflammatory cytokines and chemotactic mediators, which further facilitate the synovial tissue invasion of other immune cells [29].

Although the ability of macrophages to assume various polarising profiles including the well-defined pro-inflammatory M1 and alternative M2 polarised phenotypes is frequently observed, an increased frequency of inflammatory M1 macrophages seems to mainly characterise RA patients with high disease activity compared to RA patients under remission, who conversely show an M2 phenotype prevalence [47, 48]. Several studies highlighted the important pathogenic role of M1 monocytes/macrophages in RA. In particular, the PBMCs of RA patients show an aberrant expression of CD14 and a high expression of CD86 (M1 marker) compared to that of HS monocytes, and they are suggested to play an important role in the pathophysiological processes of the disease [48]. Furthermore, Yoon et al. found that monocytes invading the synovial tissue express higher levels of CD80 and TLR4 than peripheral blood monocytes [17]. Moreover, a recent study highlighted that the PBMCs of RA patients express several M1 macrophage molecules, including class II major histocompatibility complex molecules (HLA-DR), CD64, CD86, and CCR5, while in the synovial fluid, they show a high level of HLA-DR, CD40, CD80, CD86, and CD276 [14].

A widely known in vitro model of RA inflammation and M1 phenotype induction is represented by the stimulation of monocytes (both THP1 cell line and peripheral blood monocytes) with LPS [22, 49]. Of note, LPS is able to induce a strong upregulation of CD80 and CD86 costimulatory molecules (among M1 markers), even though it requires other binding partners to induce a robust expression of TLR4 $[50,51]$. In accordance with these observations, in our study, the upregulation of the gene expression of TLR4, CD80, and CD86 and the downregulation of that of CD163, CD204, and CD206 following LPS stimulation confirmed its ability to induce a M1 phenotype in cultured human HS-MDMs.

Our data are in line with those described by Degboe et al., although in Degboe's study, cultured HS-MDMs were stimulated with LPS in combination with IFN- $\gamma$ instead of LPS alone. However, in these cultured HSMDMs stimulated with LPS+IFN- $\gamma$, the upregulation of CD80 and the downregulation of CD163 and CD206 gene expression were observed [29]. Although the stimulation of HS-MDMs used in our study and in Degboe's study is different, the resulting induction of the polarisation into an M1 phenotype in these cultured cells seems to be very similar. Nevertheless, it is necessary to highlight that the LPS-induced polarisation of cultured HS-MDMs into a pro-inflammatory M1 phenotype represents an in vitro model, which cannot reflect the pathophysiological activity of RA macrophages. Based on this, to increase the clinical relevance of our study, the MDMs obtained from RA patients have been investigated.

It is noteworthy that monocytes/macrophages may contribute to the $\mathrm{T}$ cell activation and expansion during the inflammatory phase, thanks to their expression of HLA-DR and costimulatory molecules (CD80 and CD86), confirming their further functional role as antigen-presenting cells (APCs) [52]. In particular, to fulfil the $\mathrm{T}$ cell-naïve activation, the induction of CD80/86CD28 costimulation is needed in these APCs. This T cell-naïve activation process is inhibited by the binding of CTLA-4 to CD80/86 [52, 53].

The CTLA4-Ig fusion protein (abatacept) is a bDMARD known to modulate RA inflammation, blocking $\mathrm{T}$ cell costimulation, and its effects on different cell types, involved in the immune-inflammatory reaction, have been widely analysed and demonstrated [31, 54]. Our previous studies highlighted the efficacy of CTLA4-Ig treatment to reduce the in vitro pro-inflammatory cytokine production (IL-6, TNF $\alpha$, IL-1 $\beta$ ) as well as the CD86 expression in cultured synovial macrophages, and this effect seems to be mediated by the upregulation of the NF-kB inhibitor IkB-a [36-38]. Moreover, Rochman et al. demonstrated the effect of abatacept in reducing the gene expression of NF-kB and AP-1 transcription factors along with the remarkable proliferation decrease of $\mathrm{T}$ regulatory cells [55]. Additionally, Lorenzetti et al. reported a dose-dependent decrease of CD80 and CD86 induced by the treatment with abatacept in B cells [56]. Lastly, abatacept is involved in the synovial cell infiltration regression $[35,57]$.

Since all these observations highlight the role of abatacept in reducing the inflammatory process, the present study investigated if this anti-inflammatory effect might be linked to its ability to promote an in vitro induction of the shift from an M1 to an M2 phenotype in cultured HS-M1-MDMs and RA-MDMs. However, current data regarding the in vitro activity of bDMARD to induce the shift from M1 to M2 macrophages are limited. Recently, Degboe et al. demonstrated the ability of the anti-TNFo bDMARDs to decrease CD80 and to increase CD163 and MerTK protein synthesis in cultured polarised M1-MDMs, whereas anti-IL-6 receptor or anti-CD20 agents (such as tocilizumab and rituximab) did not induce any upregulation of M2 phenotype markers [29]. The fact that anti-IL-6 receptor agents may not affect macrophages as well as their shift into an M2 polarised status is also confirmed by Chatzidionysiou's study, in which it was demonstrated that no reduction in the number of macrophages was detectable in the synovial tissue samples of RA patients treated with tocilizumab [58]. 
The results of our study show that CTLA4-Ig treatment increased surface M2 phenotype markers (CD163, CD206, and CD204) in both cultured HS-M1-MDMs and RA-MDMs, at both gene and protein level (12 and $24 \mathrm{~h}$, respectively), with variable statistically significant results. Interestingly, CTLA4-Ig treatment seems to induce a remarkable reduction in the gene expression of M1 markers (CD80, CD86, and TLR4) already at early stage (3 h), in distinct statistically significant manner.

Therefore, our observations may suggest a rapid onset of CTLA4-Ig action on the downregulation of M1 gene expression, remaining significantly stable over time (12 h), and followed by a clear induction of M2 phenotype that might confirm the M1-M2 shift. Noteworthy, CTLA4-Ig treatment already at low dosage $(100 \mu \mathrm{M})$ seems to fulfil its maximum pharmacological action on M1 and M2 gene expression.

It should be considered that there are few "strong" monotone associations between CTLA4-Ig dosages and their modulatory effect on gene expression and protein synthesis of M1 and M2 markers in both cultured HS-M1-MDMs and RA-MDMs. It means that the gene expression or the protein synthesis (as dependent variable) always decrease (M1) or increase (M2) with the rising CTLA4-Ig dosages (as independent variable). The presence of moderate or weak associations might support the hypothesis that abatacept at early dosage (100 $\mu \mathrm{M})$ already induce the gene modulation observed in this in vitro study.

Several studies confirmed that M2 macrophages are necessary for the correct resolution of inflammation, suggesting that the induction of shift from M1 to M2 phenotype can block the progression of many rheumatic diseases, including RA [19, 47]. The upregulation of CD163 on monocytes/macrophages surface expression induced by CTLA4-Ig in our experiments may suggest that the treatment could accelerate the maturation process towards the M2 phenotype reverting the M1/M2 disequilibrium which characterises the chronic inflammation of RA.

Furthermore, the concomitant increase in gene expression and protein synthesis of CD204 and CD206 might suggest that CTLA4-Ig treatment is able to induce the shift from M1 to all well-characterised subsets of M2 macrophages compared to other bDMARDs like antiTNF- $\alpha$ bDMARDs [29]. They in fact seem to primarily promote the shift to an M2c macrophage subset, by inducing CD163 and MerTK expression through the increased production of IL-10, but not CD204 and CD206 expression, which is mediated by IL-4 instead [29]. In our in vitro study, the capability of CTLA4-Ig treatment to induce the upregulation of CD163 and MerTK gene expression, together with that of CD204 and CD206, in cultured RA-MDMs seems to promote the shift into an M2 macrophages phenotype which might have a role in the reduction of inflammation in RA patients. In support of this statement, an impressive rise in the presence of CD163 and CD206 markers on synovial tissue macrophages, together with MerTK, has been reported in RA patients in clinical remission [46]. As already mentioned, between M1 and M2, several other "M2-like" subtypes are observed; in fact, in other autoimmune connective tissue diseases, such as systemic sclerosis, circulating cells expressing both $\mathrm{M} 1$ and $\mathrm{M} 2$ phenotype markers were observed $[59,60]$. In particular, CD163 is a scavenger receptor involved in haemoglobinhaptoglobin $(\mathrm{HbHp})$ complex clearance leading to the release of IL-10 and carbon oxide (CO), which in turn exhibit strong anti-inflammatory activities [61, 62].

Besides a role in the resolution of inflammation, CD163 may also affect the initial steps of an adaptive immune response [7]. In fact, the M2 marker CD163 has been demonstrated to be involved in the adherence of human monocytes to endothelium, as well as in the inhibition of $\mathrm{T}$ lymphocyte proliferation in vitro [63, 64]. Moreover, in an ex vivo study by Ambarus et al., the presence of a cluster of CD163+ macrophages was identified in the intima layer of synovial tissue compared to the vascular/fibrous synovial layer [65].

Therefore, the shift towards CD163-expressing macrophages induced with abatacept might represent an additional aspect of its anti-inflammatory activity to attenuate inflammation in RA.

Some limitations characterise the present study. For example, even if the modulation of specific surface markers induced by CTLA4-Ig is important for the assessment of the shift from M1 towards M2 macrophages in RA, the evaluation of cytokines/chemokines produced by the M2 macrophages was not tested, to complete the evaluation, and must deserve further analysis. In addition, the less evident in vitro reactivity to the CTLA-4-Ig treatment for the RA-MDMs compared to the HS-M1-MDMs, might be partially due to the concomitant treatment of the RA patients with low-dose prednisone and/or csDMARDs [66]. However, ethical reasons justified the inclusion criteria and the concomitant minimal treatment. Finally, the limited number of RA patients analysed was due to the need to select patients with similar clinical and therapeutical characteristics.

Although this study demonstrated the in vitro capability of CTLA4-Ig to promote the shift from an M1 to an M2 phenotype in RA-MDMs, future experiments on cultured synovial macrophages need to be considered in order to improve the relevance of these results and the potential therapeutical importance of CTLA4-Ig treatment in RA patients. 
Nevertheless, based on a higher effect of the high tested CTLA4-Ig concentration $(500 \mu \mathrm{g} / \mathrm{mL})$ in increasing the protein synthesis of tested M2 markers observed in cultured HS-M1-MDMs at longer lasting period, further experiments are needed to confirm a possible dose-dependent effect also in cultured RA-MDMs. The results of the present in vitro study, together with the knowledges reported in previous studies by our group as well as other groups, suggest a contribution of CTLA4-Ig treatment in ameliorating the clinical aspect in RA patients through the downregulation of the proinflammatory status that is determined by the presence at peripheral and tissue level of M1 polarised monocytes/ macrophages which cooperate in the high disease activity. The reduction of this inflammatory status exerted by CTLA4-Ig in RA macrophages seems to occur through a rapid downregulation of specific markers of M1 phenotype (CD80, CD86, and TLR4) and the reduction of specific pro-inflammatory cytokines (IL-6, IL-1 $\beta$, and TNF $\alpha$ ), followed by the upregulation of specific markers of anti-inflammatory M2 phenotype (CD163, CD204, CD206, and MerTK). Moreover, starting from the results observed in this study, a future perspective which certainly might improve the impact of CTLA4Ig treatment should be to investigate the capability of CTLA4-Ig to induce the shift from M1 to M2 phenotype in macrophages isolated from RA patients resistant to a previous therapy with anti-TNF drugs as well as in macrophages isolated from patients characterised by genetic variability in CTLA4 (such as those with a single nucleotide polymorphism CTLA-4 rs231775) that was recently demonstrated to decrease the risk of RA [67]. Based on the results described in this in vitro study, the release of specific anti-inflammatory cytokines and chemokines in these cultured shifted RA-MDMs along with their capability to activate a T-helper 2 response will be another future perspective of this study, primarily focusing on MDMs and synovial macrophages of naïve RA patients.

\section{Conclusions}

In conclusion, the results of this in vitro study seems to indicate that abatacept can induce the M1 to M2 shift in both cultured HS-M1-MDMs and in RA-MDMs, suggesting an additional mechanism for its modulation of the RA inflammatory process [36-38].

\footnotetext{
Abbreviations

RA: Rheumatoid arthritis; M1: Classically activated macrophages; M2: Alternatively activated macrophages; CTLA4-IgG: Abatacept; HS: Healthy subjects; CD: Cluster differentiation; TLR: Toll-like receptors; MDMs: Monocyte-derived macrophages; HS-M1-MDMs: Healthy subjects'M1 monocyte-derived macrophages; RA-MDMs: Rheumatoid arthritis patients' monocyte-derived macrophages; MMPs: Matrix metalloproteinases; TNFa: Tumour necrosis factor-a; IL-1: Interleukine-1; CD204/CD163: Macrophage scavenger receptors;
}

CD206: Mannose receptor 1; TGF- $\beta$ : Transforming growth factor- $\beta$; GM-CSF: Granulocyte-macrophage colony-stimulating factor; M-CSF: Macrophage colony-stimulating factor; IFN- $\gamma$ : Interferon- $\gamma$; LPS: Lipopolysaccharides; ACPA: Anticitrullinated protein antibodies; IRF: Interferon regulatory factor; bDMARD: Biological disease-modifying antirheumatic drugs; EULAR: European League Against Rheumatism; NF-kB: Nuclear factor kappa-light-chain-enhancer of activated B cells; PCR: Polymerase chain reaction; ACR: American College of Rheumatology; NSAID: Nonsteroidal anti-inflammatory drugs; csDMARDs: Conventional synthetic disease-modifying antirheumatic drugs; PBMCs: Peripheral blood mononuclear cells; RPMl: Roswell Park Memorial Institute; PMA: Phorbol myristate acetate; qRT-PCR: Quantitative real-time polymerase chain reaction; RNA: Ribonucleic acid; cDNA: Complementary deoxyribonucleic acid; MerTK: MER proto-oncogene, tyrosine kinase; HK: Housekeeping gene; GAPDH: Glyceraldehyde 3-phosphate dehydrogenase; b-Actin: Beta-actin; UB2D2: Ubiquitin-conjugating enzyme E2 D2; RPL13A: Ribosomal protein L13a; THP1: Human monocytic leukaemia; $2^{-\triangle \triangle C T}$ : 2-Delta-delta cycle threshold; SYBR GREEN: (SG) asymmetrical cyanine dye; RIPA: Radio-immunoprecipitation assay; TrisHCl: Tris(hydroxymethyl)aminomethane-Hydrochloric acid; $\mathrm{NaCl}_{2}$ : Sodium chloride; SDS: Sodium dodecyl sulphate; EGTA: Ethylene glycol-bis( $\beta$-aminoethyl ether)-N,N, $N^{\prime}, N^{\prime}$-tetraacetic acid; EDTA: Ethylenediaminetetraacetic; $\mathrm{Na}_{3} \mathrm{VO}_{4}$ : Sodium orthovanadate; PMSF: Phenylmethylsulphonyl fluoride; BCA: Bicinchoninic acid; PBS: Phosphate-buffered saline; BSA: Bovine serum albumin; HRP: Horseradish peroxidase; S.D.: Standard deviation; FCgRIII: Fragment crystallizable g receptor III; HLA-DR: Human leukocyte antigen-DR isotype; APC: Antigen-presenting capacity; CTLA-4: Cytotoxic T lymphocyteassociated protein 4; IkB-a: Nuclear factor of kappa light polypeptide gene enhancer in B cell inhibitor alpha.

\section{Supplementary Information}

The online version contains supplementary material available at https://doi. org/10.1186/s13075-021-02691-9.

Additional file 1: Figure S1. Gene expression of $M 1$ and $M 2$ markers in cultured THP1-derived macrophages stimulated with LPS and a combination of LPS and IFN- $\gamma$. Quantitative real time PCR of M1 markers (TLR4, CD80, CD86) or M2 markers (CD163, CD204, CD206) in cultured THP1derived macrophages maintained in normal growth medium without any stimulation (white bar), stimulated with LPS alone $(1 \mathrm{mg} / \mathrm{ml})$ (light grey bar) or stimulated with LPS $(1 \mathrm{mg} / \mathrm{ml})$ in combination with interferon- $\gamma$ (IFN- $\gamma$ 20ng/ml) (black bar) for 3 and 12 hrs. (A) M1 markers (TLR4, CD80, CD86); (B) M2 markers (CD163, CD204, CD206). Final results were obtained from five independent in vitro experiments.

Additional file 2: Figure S2. Gene expression of $\mathrm{M} 1$ and $\mathrm{M} 2$ markers in cultured human monocyte-derived macrophages stimulated with LPS and a combination of LPS and IFN- $\gamma$. Quantitative real time PCR of M1 markers (TLR4, CD80, CD86) or M2 markers (CD163, CD204, CD206) in cultured monocyte-derived macrophages obtained from healthy subjects and maintained in normal growth medium without any stimulation (white bar), stimulated with LPS alone ( $1 \mathrm{mg} / \mathrm{ml}$ ) (light grey bar) or stimulated with LPS $(1 \mathrm{mg} / \mathrm{ml})$ in combination with interferon- $\gamma($ IFN- $\gamma 20 \mathrm{ng} / \mathrm{ml})$ (black bar) for 3 and 12 hrs. (A) M1 markers (TLR4, CD80, CD86); (B) M2 markers (CD163, CD204, CD206). Final results were obtained from five independent in vitro experiments.

Additional file 3: Figure S3. Timeline of the experimental design. Timeline of the experimental design planned for the stimulation and treatment of cultured cells used for the in vitro experiments. Experimental design 1: Monocytes were obtained from peripheral blood mononuclear cells isolated from healthy subjects (HS PBMCs) after adhesion of 24 hrs in cell growth medium (RPMI at 10\% of fetal bovine serum) and removal of T and $B$ cells. Then monocytes were stimulated with phorbol myristate acetate (PMA $5 \mathrm{ng} / \mathrm{ml}$ ) for $24 \mathrm{hrs}$ to induce their differentiation into monocytederived macrophages (MDMs). Culture MDMs were maintained in growth medium without stimulation or treatment (unstimulated), stimulated with LPS $(1 \mathrm{mg} / \mathrm{ml})$, stimulated with LPS $(1 \mathrm{mg} / \mathrm{ml})$ for $4 \mathrm{hrs}$ and then treated with CTLA4-lg $(100 \mu \mathrm{g} / \mathrm{mL})$, stimulated with LPS $(1 \mathrm{mg} / \mathrm{ml})$ for $4 \mathrm{hrs}$ and then treated with CTLA4- $\lg (500 \mu \mathrm{g} / \mathrm{mL})$. Experimental design 2: Monocytes were obtained from peripheral blood mononuclear cells isolated from rheumatoid arthritis patients (RA PBMCs) after adhesion of $24 \mathrm{hrs}$ in cell 
growth medium (RPMI at 10\% of fetal bovine serum) and removal of T and $\mathrm{B}$ cells. Then monocytes were stimulated with phorbol myristate acetate (PMA 5ng/ml) for 24 hrs to induce their differentiation into monocytederived macrophages (MDMs). Culture MDMs were maintained in growth medium without stimulation or treatment (unstimulated), treated with CTLA4-lg $(100 \mu \mathrm{g} / \mathrm{mL})$, treated with CTLA4-lg $(500 \mu \mathrm{g} / \mathrm{mL})$. Gene expression was investigated after 3 and 12 hrs by quantitative real-time polymerase chain reaction, whereas protein synthesis was investigated by Western blotting (and related densitometric analysis) after 24 and 48 hrs of stimulation and treatment.

Additional file 4: Figure S4. Gene expression of M1 markers in cultured human monocyte-derived macrophages obtained from healthy subjects and RA patients. Quantitative real time PCR of M1 markers (TLR4, CD80, CD86) in cultured monocyte-derived macrophages (MDMs) obtained from healthy subjects (white bar) and rheumatoid arthritis patents (black bar) maintained in normal growth medium without any stimulation for 3 and $12 \mathrm{hrs}$. Final results were obtained from five independent in vitro experiments.

\section{Acknowledgements}

We really thank Dr. Luca Carmisciano for the support in the statistical analysis.

\section{Authors' contributions}

M.C. planned the study design, revised the manuscript for critical important result discussion, and corrected and approved the final text. S.S. performed the protein evaluation and analysis, contributed to the planning of the experimental design, comprehended the data and result, and wrote the manuscript. E.G. was involved in the data plotting and analysis and helped to write the results. P.M. obtained the cells from blood samples and was involved in the data plotting and analysis. R.C. was involved in the data plotting, organisation of data, and statistical analysis. S.P., C.P., and A.S. were involved in the selection and sampling of the healthy subjects and RA patients and the collection of informed consents and EC contacts. V.S. was involved in the planning of the study and in critical revision of the discussion. S.T. planned the design of the experiments, performed the MDM cell cultures and treatments for in vitro experiments, analysed the results, and helped to write the manuscript. All authors read and approved the final manuscript. All data generated or analysed during this study are included in this published article.

\section{Funding}

This work was supported by a study grant from Bristol Mayer Squibb (BMS) (study ID: IM101-811).

\section{Availability of data and materials}

All data generated or analysed during this study are included in this published article [and its supplementary information files]. Data are available upon request to qualified investigators.

\section{Declarations}

\section{Ethics approval and consent to participate}

The study was approved by the local Ethical Board Committee. The protocol ID is 2015-002729-21. All healthy subjects enrolled in the study gave signed informed consent.

\section{Consent for publication}

Not applicable

\section{Competing interests}

M.C. received a grant provided by BMS for the present in vitro study (study ID: IM101-811). All other authors declared that they have no competing interests.

\section{Author details}

'Laboratory of Experimental Rheumatology and Academic Division of Clinical Rheumatology, Department of Internal Medicine, IRCCS San Martino Polyclinic Hospital, University of Genova, Genoa, Italy. ${ }^{2}$ Department of Rheumatology, Ghent University Hospital, Ghent, Belgium. ${ }^{3}$ Department of Internal
Medicine, Ghent University, Ghent, Belgium. ${ }^{4}$ Unit for Molecular Immunology and Inflammation, VIB Inflammation Research Center (IRC), Ghent, Belgium.

Received: 26 July 2021 Accepted: 3 December 2021

Published online: 24 December 2021

\section{References}

1. Guo Q, Wang Y, Xu D, Nossent J, Pavlos NJ, Xu J. Rheumatoid arthritis: pathological mechanisms and modern pharmacologic therapies. Bone Res. 2018;6:15. https://doi.org/10.1038/s41413-018-0016-9.

2. Smolen JS, Aletaha D, McInnes IB. Rheumatoid arthritis. Lancet. 2016;388:2023-38.

3. McInnes IB, Schett $G$. The pathogenesis of rheumatoid arthritis. N Engl J Med. 2011;365:2205-19.

4. Mills CD. Anatomy of a discovery: M1 and M2 macrophages. Front Immunol. 2015;5:212. https://doi.org/10.3389/fimmu.2015.00212.

5. Mills CD. M1 and M2 macrophages: oracles of health and disease. Crit Rev Immunol. 2012:32:463-88.

6. Cutolo M. Macrophages as effectors of the immunoendocrinologic interactions in autoimmune rheumatic diseases. Ann NY Acad Sci. 1999;876:32-42.

7. Li J, Hsu HC, Mountz JD. Managing macrophages in rheumatoid arthritis by reform or removal. Curr Rheumatol Rep. 2012;14:445-54.

8. Szekanecz Z, Koch AE. Macrophages and their products in rheumatoid arthritis. Curr Opin Rheumatol. 2007;19:289-95.

9. Mantovani A, Sica A, Sozzani S, Allavena P, Vecchi A, Locati M. The chemokine system in diverse forms of macrophage activation and polarization. Trends Immunol. 2004;25:677-86.

10. Udalova IA, Mantovani A, Feldmann M. Macrophage heterogeneity in the context of rheumatoid arthritis. Nat Rev Rheumatol. 2016;12:472-85.

11. Tardito S, Martinelli G, Soldano S, Paolino S, Pacini G, Patane M, et al. Macrophage M1/M2 polarization and rheumatoid arthritis: a systematic review. Autoimmun Rev. 2019;18:102397. https://doi.org/10.1016/j.autrev.2019.102397.

12. Zhang H, Cai D, Bai X. Macrophages regulate the progression of osteoarthritis. Osteoarthr Cartil. 2020;28:555-61.

13. Mosser DM, Edwards JP. Exploring the full spectrum of macrophage activation. Nat Rev Immunol. 2008;8:958-69.

14. Yang $X$, Chang $Y$, Wei $W$. Emerging role of targeting macrophages in rheumatoid arthritis: focus on polarization, metabolism and apoptosis. Cell Prolif. 2020;53:e12854. https://doi.org/10.1111/cpr.12854.

15. Quero L, Hanser E, Manigold T, Tiaden AN, Kyburz D. TLR2 stimulation impairs anti-inflammatory activity of M2-like macrophages, generating a chimeric M1/M2 phenotype. Arthritis Res Ther. 2017;19:245-58. https:// doi.org/10.1186/s13075-017-1447-1.

16. Wang Y, Han C, Cui D, Li Y, Ma Y, Wei W. Is macrophage polarization important in rheumatoid arthritis? Int Immunopharmacol. 2017;50:345-52.

17. Yoon BR, Yoo S-J, Ho CY, Chung Y-H, Kim J, Yoo IS, et al. Functional phenotype of synovial monocytes modulating inflammatory T-cell responses in rheumatoid arthritis (RA). PLoS One. 2014;9:e109775. https://doi.org/10. 1371/journal.pone.0109775.

18. Smiljanovic B, Radzikowska A, Kuca-Warnawin E, Kurowska W, Grün JR, Stuhlmüller B, et al. Monocyte alterations in rheumatoid arthritis are dominated by preterm release from bone marrow and prominent triggering in the joint. Ann Rheum Dis. 2018;77:300-8.

19. Kennedy A, Fearon U, Veale DJ, Godson C. Macrophages in synovial inflammation. Front Immunol. 2011;2:52. https://doi.org/10.3389/fimmu.2011.00052.

20. Gu Q, Yang H, Shi Q. Macrophages and bone inflammation. J Orthop Transl. 2017;10:86-93.

21. McInnes IB, Schett G. Cytokines in the pathogenesis of rheumatoid arthritis. Nat Rev Immunol. 2007;7:429-42.

22. Pelegrin P, Surprenant A. Dynamics of macrophage polarization reveal new mechanism to inhibit IL-1B release through pyrophosphates. EMBO J. 2009;28:2114-27.

23. Mantovani A, Sozzani S, Locati M, Allavena P, Sica A. Macrophage polarization: tumor-associated macrophages as a paradigm for polarized M2 mononuclear phagocytes. Trends Immunol. 2002;23:549-55.

24. Mia S, Warnecke A, Zhang X-M, Malmström V, Harris RA. An optimized protocol for human M2 macrophages using M-CSF and IL-4/IL-10/TGF- $\beta$ yields a dominant immunosuppressive phenotype. Scand J Immunol. 2014;79:305-14. 
25. Gordon S, Taylor PR. Monocyte and macrophage heterogeneity. Nat Rev Immunol. 2005;5:953-64.

26. Zhu W, Li X, Fang S, Zhang X, Wang Y, Zhang T, et al. Anti-citrullinated protein antibodies induce macrophage subset disequilibrium in RA patients. Inflammation. 2015;38:2067-75.

27. Parisi L, Gini E, Baci D, Tremolati M, Fanuli M, Bassani B, et al. Macrophage polarization in chronic inflammatory diseases: killers or builders? J Immunol Res. 2018;2018:1-25.

28. Horuluoglu B, Bayik D, Kayraklioglu N, Goguet E, Kaplan MJ, Klinman DM. PAM3 supports the generation of M2-like macrophages from lupus patient monocytes and improves disease outcome in murine lupus. J Autoimmun. 2019;99:24-32.

29. Degboé Y, Rauwel B, Baron M, Boyer J-F, Ruyssen-Witrand A, Constantin A et al. Polarization of rheumatoid macrophages by TNF targeting through an IL-10/STAT3 mechanism. Front Immunol. 2019;10. https://doi.org/10. 3389/fimmu.2019.00003.

30. Smolen JS, Landewé RBM, Bijlsma JWJ, Burmester GR, Dougados M, Kerschbaumer A, et al. EULAR recommendations for the management of rheumatoid arthritis with synthetic and biological disease-modifying antirheumatic drugs: 2019 update. Ann Rheum Dis. 2020;79:S685-99.

31. Picchianti Diamanti A, Rosado MM, Scarsella M, Germano V, Giorda E, Cascioli S, et al. Abatacept (cytotoxic T lymphocyte antigen 4-immunoglobulin) improves B cell function and regulatory $T$ cell inhibitory capacity in rheumatoid arthritis patients non-responding to anti-tumour necrosis factor-a agents. Clin Exp Immunol. 2014;177:630-40.

32. Cutolo M, Sulli A, Paolino S, Pizzorni C. CTLA-4 blockade in the treatment of rheumatoid arthritis: an update. Expert Rev Clin Immunol. 2016;12:417-25.

33. Rubbert-Roth A, Enejosa J, Pangan AL, Haraoui B, Rischmueller M, Khan $\mathrm{N}$, et al. Trial of upadacitinib or abatacept in rheumatoid arthritis. N Engl J Med. 2020;383:1511-21.

34. Triaille C, Durez P, Sokolova T, Tilman G, Méric de Bellefon L, Galant C, et al. Common transcriptomic effects of abatacept and other DMARDs on rheumatoid arthritis synovial tissue. Front Immunol. 2021;12:3419. https://doi.org/10.3389/fimmu.2021.724895.

35. Fujii M, Inoguchi T, Batchuluun B, Sugiyama N, Kobayashi K, Sonoda N, et al. CTLA-4lg immunotherapy of obesity-induced insulin resistance by manipulation of macrophage polarization in adipose tissues. Biochem Biophys Res Commun. 2013;438:103-9.

36. Brizzolara R, Montagna P, Soldano S, Cutolo M. Rapid interaction between CTLA4-lg (abatacept) and synovial macrophages from patients with rheumatoid arthritis. J Rheumatol. 2013;40:738-40.

37. Brizzolara R, Soldano S, Montagna P, Sulli A, Seriolo B, Villaggio B, et al. CTLA4Ig interferes and downregulates the proinflammatory activities of rheumatoid synovial macrophages in monoculture. Reumatismo. 2011;63:80-5.

38. Cutolo M, Soldano S, Montagna P, Sulli A, Seriolo B, Villaggio B, et al. CTLA4-Ig interacts with cultured synovial macrophages from rheumatoid arthritis patients and downregulates cytokine production. Arthritis Res Ther. 2009;11:R176. https://doi.org/10.1186/ar2865.

39. Aletaha D, Neogi T, Silman AJ, Funovits J, Felson DT, Bingham CO, et al. 2010 rheumatoid arthritis classification criteria: an American College of Rheumatology/European league against rheumatism collaborative initiative. Arthritis Rheum. 2010;62:2569-81

40. Cutolo M, Paolino S, Pizzorni C, Sulli A, Seriolo B, Cimmino MA, et al. Effects of combined treatments with CTLA4-IG (abatacept), dexamethasone and methotrexate on cultured human macrophages. Clin Exp Rheumatol. 2016;34:500-6.

41. Cutolo M, Soldano S, Contini P, Sulli A, Seriolo B, Montagna P, et al. Intracellular NF-kkB decrease and IKBaa increase in human macrophages following CTLA4-Ig treatment. Clin Exp Rheumatol. 2013;31:943-6.

42. Ledderose C, Heyn J, Limbeck E, Kreth S. Selection of reliable reference genes for quantitative real-time PCR in human T cells and neutrophils. BMC Res Notes. 2011;4:427. https://doi.org/10.1186/1756-0500-4-427.

43. Livak KJ, Schmittgen TD. Analysis of relative gene expression data using real-time quantitative PCR and the 2- $\triangle C T$ method. Methods. 2001:25:402-8.

44. Schober P, Schwarte LA. Correlation coefficients: appropriate use and interpretation. Anesth Analg. 2018;126:1763-8.

45. Gust $L$, D'journo XB. The use of correlation functions in thoracic surgery research. J Thorac Dis. 2015;7:E11-5. https://doi.org/10.3978/j.issn.20721439.2015.01.54.
46. Alivernini S, MacDonald L, Elmesmari A, Finlay S, Tolusso B, Gigante MR, et al. Distinct synovial tissue macrophage subsets regulate inflammation and remission in rheumatoid arthritis. Nat Med. 2020;26:1295-306.

47. Laria A, Lurati A, Marrazza M, Mazzocchi D, Re KA, Scarpellini M. The macrophages in rheumatic diseases. J Inflamm Res. 2016;9:1-11.

48. Nathan C, Ding A. Nonresolving inflammation. Cell. 2010;140:871-82.

49. Martinez FO, Gordon S. The M1 and M2 paradigm of macrophage activation: time for reassessment. F1000Prime Rep. 2014;6:6-13.

50. Ryszard R, Moniuszko T, Stasiak-Barmuta A, Kosztyła-Hojna B, Alifier M, Krzysztof Rutkowski AT-K. CD80 and CD86 expression on LPS-stimulated monocytes and the effect of CD80 and CD86 blockade on IL-4 and IFN-gamma production in nonatopic bronchial asthma. Arch Immunol Ther Exp. 2003;51:421-8.

51. Wan J, Shan Y, Fan Y, Fan C, Chen S, Sun J, et al. NF-kB inhibition attenuates LPS-induced TLR4 activation in monocyte cells. Mol Med Rep. 2016;14:4505-10

52. Geissmann F, Auffray C, Palframan R, Wirrig C, Ciocca A, Campisi L, et al. Blood monocytes: distinct subsets, how they relate to dendritic cells, and their possible roles in the regulation of T-cell responses. Immunol Cell Biol. 2008;86:398-408.

53. Blair HA, Deeks ED. Abatacept: a review in rheumatoid arthritis. Drugs. 2017;77:1221-33

54. Bonelli M, Scheinecker C. How does abatacept really work in rheumatoid arthritis? Curr Opin Rheumatol. 2018;30:295-300.

55. Rochman Y, Yukawa M, Kartashov AV, Barski A. Functional characterization of human T cell hyporesponsiveness induced by CTLA4-lg. PLoS One. 2015;10:e0122198. https://doi.org/10.1371/journal.pone.0122198.

56. Lorenzetti R, Janowska I, Smulski CR, Frede N, Henneberger N, Walter L, et al. Abatacept modulates CD80 and CD86 expression and memory formation in human B-cells. J Autoimmun. 2019;101:145-52.

57. Cañete JD, Celis R, Hernández V, Pablos JL, Sanmartí R. Synovial immunopathological changes associated with successful abatacept therapy in a case of severe refractory psoriatic arthritis. Ann Rheum Dis. 2010;69:935-6.

58. Chatzidionysiou K, Circiumaru A, Rethi B, Joshua V, Engstrom M, Hensvold A, et al. Tocilizumab decreases $T$ cells but not macrophages in the synovium of patients with rheumatoid arthritis while it increases the levels of serum interleukin-6 and RANKL. RMD Open. 2021;7(2):e001662. https:// doi.org/10.1136/rmdopen-2021-001662.

59. Trombetta AC, Soldano S, Contini P, Tomatis V, Ruaro B, Paolino S, et al. A circulating cell population showing both $\mathrm{M} 1$ and $\mathrm{M} 2$ monocyte/macrophage surface markers characterizes systemic sclerosis patients with lung involvement. Respir Res. 2018;19:186. https://doi.org/10.1186/ar3796.

60. Soldano S, Trombetta AC, Contini P, Tomatis V, Ruaro B, Brizzolara R, et al. Increase in circulating cells coexpressing M1 and M2 macrophage surface markers in patients with systemic sclerosis. Ann Rheum Dis. 2018;77:1842-5.

61. Rőszer T. Understanding the mysterious M2 macrophage through activation markers and effector mechanisms. Mediat Inflamm. 2015:2015:1-16.

62. Shrivastava R, Shukla N. Attributes of alternatively activated (M2) macrophages. Life Sci. 2019;224:222-31.

63. Wenzel I, Roth J, Sorg C. Identification of a novel surface molecule, RM3/1, that contributes to the adhesion of glucocorticoid-induced human monocytes to endothelial cells. Eur J Immunol. 1996;26:2758-63.

64. Högger P, Sorg C. Soluble CD163 inhibits phorbol ester-induced lymphocyte proliferation. Biochem Biophys Res Commun. 2001;288:841-3.

65. Ambarus CA, Noordenbos T, de Hair MJH, Tak PP, Baeten DLP. Intimal lining layer macrophages but not synovial sublining macrophages display an IL-10 polarized-like phenotype in chronic synovitis. Arthritis Res Ther. 2012;14:R74. https://doi.org/10.1186/ar3796.

66. Cutolo M, Paolino S, Gotelli E. Glucocorticoids in rheumatoid arthritis still on first line: the reasons. Expert Rev Clin Immunol. 2021;17:417-20.

67. Liu W, Yang Z, Chen Y, Yang H, Wan X, Zhou X, et al. The association between CTLA-4, CD80/86, and CD28 gene polymorphisms and rheumatoid arthritis: an original study and meta-analysis. Front Med. 2021;8:57. https://doi.org/10.3389/fmed.2021.598076.

\section{Publisher's Note}

Springer Nature remains neutral with regard to jurisdictional claims in published maps and institutional affiliations. 